[Vol. 103

\title{
NOTES
}

\section{INTERPRETATION AND APPLICATION OF SECTION 301(a) OF THE LABOR-MANAGEMENT RELATIONS ACT}

\section{INTRODUCTION}

The purpose of Title III of the Labor-Management Relations Act is to equalize the legal responsibilities of labor organizations and employers, ${ }^{1}$ and liability for breach of collective bargaining agreements was one of the more important areas in which the Eightieth Congress considered legislation necessary to accomplish this purpose. The inequality which the legislation sought to remedy stemmed from the difficulty of subjecting unions to suit. Unions, as unincorporated associations, cannot be sued at common law as an entity, and their assets were difficult to reach. Consequently, the legislators felt that union breaches were "acts for which, under existing laws, unions . . often escape liability but for which all other citizens must answer in court." 2 Although in most states the inequality does not exist because the common-law rules are not applied," the desired mutuality of responsibility could not be fully attained "until all jurisdictions, and particularly the Federal Government, authorized actions against labor unions as legal entities." 4

The statutory plan to achieve the ultimate objective of mutual enforcement of the collective bargaining agreements is embodied in Section 301. Subsection (b) provides that "any such labor organization may sue or be sued as an entity and in behalf of the employees whom it represents in the courts of the United States." "While this provision would eliminate the cause of the inequality in the suits to which it can be applied, it does not confer jurisdiction. ${ }^{6}$ In order to eliminate obstacles to enforceability of the agreements generally, it was necessary to bring the suits for violation of the agreements within the operation of Section 301(b), that is, to permit the suits to be brought in the federal courts. This func-

1. 61 Stat. 136 (1947), 29 U.S.C. § 141 (1952).

2. H.R. Rep. No. 245, 80th Cong., 1st Sess. 8 (1947).

3. For a summary of the status of labor unions in the state courts see Kaye \& Allen, Union Responsibility and the Enforcement of Collective Bargaining Agreements, 30 B.U.L. Rev. 1, 7-15 (1950) ; H.R. Minority ReP. No. 245, 80th Cong., 1st Sess. 108 (1947). At the passage of the Act there were only 13 states in which unions were not amenable to suit as an entity.

4. Sen. Rep. No. 105, 80th Cong., 1st Sess. 17 (1947).

5. 61 Stat. 157 (1947), 29 U.S.C. $\$ 185$ (b) (1952).

6. Murphy v. Hotel Employees Union, AFL, 102 F. Supp. 488 (E.D. Mich. 1951) ; Kriss v. White, 87 F. Supp. 734 (N.D.N.Y. 1949); see Amazon Cotton Mill Co. v. Textile Workers Union, CIO, 167 F.2d 183, 188 (4th Cir. 1948); Square D Co. v. United Elec. Workers Union, 123 F. Supp. 776, 782 (E.D. Mich. 1954); Rock Drilling Union v. Mason \& Hangar Co., 90 F. Supp. 539, 542 (S.D.N.Y. 1950). 
tion is performed by the jurisdictional grant of Section 301(a), which thus is the crux of the legislative scheme.

Section 301(a) provides that:

"Suits for violation of contracts between an employer and a labor organization representing employees in an industry affecting commerce as defined by this Act, or between any such labor organizations, may be brought in any district court of the United States having jurisdiction of the parties, without respect to the amount in controversy or without regard to the citizenship of the parties." 7

The enactment of this section presents difficulties which the Congress did not foresee and which almost five years of judicial construction have failed to settle. Conflicting theories and different results are found in almost every situation in which the section is relied upon. For example, in the only case in which the Supreme Court has intervened, ${ }^{8}$ the net result of the decision was to exclude from the coverage of the section a type of suit which almost all of the lower courts had assumed to be included and to raise doubts about the constitutionality of the section. The following discussion examines four separate problems which the enactment of Section 301(a) has raised: (1) the scope and constitutionality of the section; (2) its effect upon the enforcement of arbitration clauses; (3) the relief available; and (4) the parties which are properly within the section's jurisdictional grant.

\section{Constitutionality and Scope of Section 301 (a)}

\section{Constitutional Theories and Congressional Intent}

On its face Section 301(a) is merely a grant of federal jurisdiction over suits for violation of labor contracts. The section expressly eliminates any requirement of diversity of citizenship, and therefore its constitutionality hinges upon a determination of whether suits under it fall within the "arising under . . . the Laws of the United States" clause of Article III of the Constitution. ${ }^{9}$ Neither this section nor any other in the national labor statutes explicitly creates or recognizes any privately enforceable rights which attach to labor contracts. Thus, there is an apparent lack of a federal substantive law under which every suit for violation of such a contract could be said to "arise." 10 However, if the section is construed as a direction to supply and develop a federal common law to govern

7. 61 StaT. 156 (1947), 29 U.S.C. §185(a) (1952).

8. Association of Westinghouse Salaried Employees v. Westinghouse Elec. Corp., 75 Sup. Ct. 488 (1955). See text at notes 33-37, 205-16 infra.

9. But cf. text at notes 21-24 infra. U.S. ConsT. Art. III, \&2 provides: "The judicial Power shall extend to all Cases .... arising under... the Laws of the United States. ...."

10. Even if some specific rights attaching to collective bargaining agreements were to be found elsewhere in the federal statutes, these rights could not be relied upon to sustain a grant of jurisdiction over cases not involving those rights. 
the rights of the parties, the adjudication of cases arising under this federal law would be well within the judicial power. ${ }^{11}$ If this construction is not adopted, serious theoretical difficulties are presented; ${ }^{12}$ but the absence of a governing federal substantive law is not in itself conclusive of invalidity. In the landmark case of Osborn v. Bank of the United States ${ }^{13}$ the Supreme Court upheld a grant of federal jurisdiction over all suits to which the bank was a party, ${ }^{14}$ including suits which did not involve the interpretation of the statute creating the bank and which were governed by state commercial law. The Court reasoned that the existence of the charter supplied the necessary federal "original ingredient" 15 in every suit. However, an analogy to the Osborn case, through substitution of the union or the employer for the bank, does not sustain the 301 (a) grant; neither is a federal entity as was the bank, which derived its existence and all its faculties from the act of Congress creating it. ${ }^{16}$ Employers and unions are neither created nor empowered to act by federal authority ${ }^{17}$ and consequently the necessary federal ingredient must be found elsewhere than in the identity of the parties.

This element can more easily be discovered by reference to the contract. The section also can be construed as establishing as substantive law only the principle that labor contracts shall be legally binding upon the contracting parties, leaving the existence and interpretation of a particular right under a particular contract to be determined by state law. Such a jurisdictional grant would be within the Osborn holding because the question of the enforceability of the contract, like the ability of the bank to sue or be sued, would lie at the foundation of the cause to which jurisdiction is extended. To paraphrase the language of the Court, "The right to sue (in the case of Section 301 (a) the enforceability of the contract), if decided once, is decided forever; but the power of Congress was exer-

11. See Mishkin, The Federal "Question" in the District Courts, 53 CoL. L. REv. 157, 186 (1953).

12. These problems are extensively and authoritatively discussed in Mishkin, supra note 11, at 186-96; Forrester, The Jurisdictioin of Federal Courts in Labor Disputes, 13 IAW \& CoNTEMP. ProB. 114, 118-31 (1948); Note, 57 Yale I.J. 630 (1948); see also Wallace, The Contract Cause of Action Under the Taft-Harlley Act, 16 BROOKLYN L. REv. 1 (1949).

13. 9 Wheat. 738 (U.S. 1824).

14. 3 STAT. 269 (1816).

15. Osborn v. Bank of the United States, 9 Wheat. 738, 824 (U.S. 1824).

16. $I d$. at 823 .

17. See Forrester, The Jurisdiction of the Federal Courts in Labor Disputes, 13 LAW \& CONTEMP. PrOB. 114, 124, 129 (1948). Employers could hardly be considered federally-created entities in any sense. Section 301(b), 61 STAT. 156 (1947), 29 U.S.C. $\$ 185$ (1952), which provides that a union "may sue and be sued as an entity . . . in the courts of the United States" cannot be said to create a union entity in the sense that the bank was created, because the union is made an entity only for the purposes of suit in the federal courts. Union status in the state courts is unaffected. Bunch v. Launius, 222 Ark. 760, 262 S.W.2d 461 (1953). Even in the federal courts unions are not always treated as entities. For example, they may still bring a class suit, Tisa v. Potofsky, 90 F. Supp. 175 (S.D.N.Y. 1950), and citizenship for diversity purposes is determined by the citizenship of the individual parties. Murphy v. Hotel \& Restaurant Employees, AFL, 102 F. Supp. 488 (E.D. Mich. 1951); Brooks v. Hunkin-Conkey Construction Co., 95 F. Supp. 608 (W.D. Pa. 1951). 
cised antecedently to the first decision on that right, and if it was constitutional then, it cannot cease to be so because the particular question is decided. . . . The question forms an original ingredient in every cause." 18

If the Osborn case is deemed to have established the propriety of utilizing the federal courts as a protective haven for a federal legislative plan, ${ }^{19}$ Section 301(a) would be constitutional even if construed as only a procedural measure. Under this theory, federal jurisdiction is necessary to protect the congressional regulatory scheme in the field of labor relations. Even though state law would be controlling, the federal courts' knowledge and receptiveness to the national policy would insure a fairer and more proper application than would exist in the state courts. Similarly, it was necessary that the bank in Osborn be protected from discrimination by the state courts, and federal judicial administration was invoked as the protective agency. Such suits are said to be within Article III because they arise under the laws which comprise the legislative program which is being protected. However, the courts have not as yet employed the protective theory as their sole basis for upholding the constitutionality of a statute and doubt has been expressed as to the theory's validity. ${ }^{20}$

A possibility that the 301(a) grant of jurisdiction may be sustained as a valid exercise of the Article I power to regulate commerce, without reference to Article III, is raised by the rationale of three of the Supreme Court justices in National Insurance Co. v. Tidezrater Co., ${ }^{21}$ which upheld that section of the Judicial Code ${ }^{22}$ opening the federal district courts to suits between citizens of the District of Columbia and citizens of a state. Justices Black, Burton and Jackson reasoned that the legislation was valid as an exercise of Congress' power over the District under Article I. ${ }^{23}$ This view lacked a majority of the Court, as six justices explicitly rejected the Article I approach. ${ }^{24}$ The Article I theory apparently is limited only by the requirement that the jurisdictional grant be in an area over which Congress possesses legislative powers. Since collective bargaining in industries affecting commerce is clearly subject to federal regulation under the commerce clause, even an interpretation of Section 301 (a) as merely

18. 9 Wheat. 738, 824 (U.S. 1824).

19. See Mishkin, supra note 11 , at 187-96.

20. See the opinion of Justice Frankfurter in Association of Westinghouse Salaried Employees v. Westinghouse Elec. Corp., 75 Sup. Ct. 488, 495-96 (1955).

21. 337 U.S. 582 (1949).

22. 28 U.S.C. $\$ 1332$ (1952).

23. The Article I approach was made necessary by the unwillingness to overrule the case of Hepburn \& Dundas v. Ellzey, 2 Cranch 445 (U.S. 1805), which relied heavily on the interpretation of the language of the Constitution in holding that a citizen of the District of Columbia was not a citizen of a state within the meaning of the Judiciary Act of 1789, 1 STAT. 78 (1789) (now as amended, 28 U.S.C. \$1332 (1952)).

24. Justices Rutledge and Murphy concurred on the ground that the District of Columbia was a state within the meaning of Article III, and Chief Justice Vinson and Justices Reed, Frankfurter, and Douglas dissented. 
a procedural measure would be sustained if the theory should be accepted by a majority of the Supreme Court.

The legislative history contains no indication of congressional reliance upon a particular theory under which Section 301 (a) was considered to be constitutional. The constitutional problems inherent in the section's purely jurisdictional language were recognized only by the House ${ }^{25}$ and Senate ${ }^{26}$ committee minorities and their objections went unanswered. The general expressions of the purpose of the section point to the conclusion that Congress intended 301 (a) to have substantive content, but that it be limited to the principle of enforceability. The attention of Congress was focused upon the fact that the labor union entity, because of its status as an unincorporated association, was not liable to suit for violation of collective bargaining agreements. Although legislative intent could be logically separable into a substantive end, attaching legally enforceable consequences to collective bargaining agreements, and a procedural means, removing the procedural obstacles to enforcement against unions, congressional language contains both procedural and substantive elements. The House Report states that unions must be subject to judicial remedies if they are to be treated as responsible contracting parties, ${ }^{27}$ and therefore Section 301 (a) "makes labor organizations equally responsible with employers for contract violations and provides for suit by either against the other in the United States district courts." 28 The Senate Report described the Senate provision as one to "equalize legal responsibilities of labor organizations" 29 by making "collective-bargaining contracts equally binding and enforceable on both parties." 30 After reciting the difficulties in enforcing those contracts against labor unions, and deciding that actions against labor unions are necessary to "vitalize collective-bargaining agreements," the Report concludes that "statutory recognition of the collective agreements as a valid, binding and enforceable contract is a logical and necessary step." 31 The meager statements during debate reflect a greater degree of preoccupation with the procedural aspect of the measure than do the committee reports. ${ }^{32}$

25. H.R. REP. No. 245, 80th Cong., 1st Sess. 109-10 (1947).

26. SEN. Rep. No. 105, 80th Cong., 1st Sess. pt. 2, at 14 (1947).

27. H.R. REp. No. 245, 80th Cong., 1st Sess. 46 (1947).

28. $I d$. at 6.

29. Sen. Rep. No. 105, 80th Cong., 1st. Sess. pt. 1, at 1 (1947).

30. Id. at 15 .

31. Id. at 17.

32. See, e.g., Representative Case: ". . . the bill establishes suability for and by labor organizations as entities." 93 CoNG. Rec. 6283 (1947). Senator Taft: "The bill makes unions suable in the federal courts for violation of a contract . . as if they were corporations. . . "93 Cong. REc. 3839 (1947). "The purpose of title III is to give employer and the employee the right to go to the Federal courts to bring a suit to enforce the terms of a collective-bargaining agreement. . . ." 93 CoNG. REC. 4141 (1947). "If we are to have free collective bargaining it must be between two responsible parties. . . There is no reason in the world why a union should not have the same responsibility that a corporation has. . . So we have provided that a union may sue and be sued as if it were a corporation." 93 Cong. REC. 7537 (1947). 
Even standing alone, this emphasis on procedural reform is consistent with the conclusion that Section 301(a) creates a substantive law of enforceability. Constituting the union an entity for the purposes of suit was but a step in the direction of making these agreements enforceable as are any other contracts. However, no evidence can be found that Congress intended to create a complete body of federal common law nor that the legislators realized that Section 301(a) would possibly have this result; and the existing statutory language is quite inappropriate to fulfill any such intention. Since it would have been comparatively easy for Congress explicitly to have directed the federal courts to apply a newly created federal common law had it desired to do so, the substantive content of the section should be limited to the principle of enforceability.

\section{Judicial Interpretations}

The Supreme Court decision in Ass'n of Westinghouse Salaried Employees v. Westinghouse Elec. Corp..$^{33}$ produced a three to three division of opinion on the constitutional question; ${ }^{34}$ but the Court by a vote of six to two dismissed on the ground that the particular suit, a union's suit on behalf of 4000 employees for wages due, was not within the coverage of Section 301(a). Justice Frankfurter, in an opinion joined by Justices Burton and Minton, voted for dismissal principally because the doubtful validity of the section justified a narrow reading as a means of avoiding decision of the constitutional issue. After an examination of the legislative history Justice Frankfurter concluded that the section was purely procedural and that the difficulties inherent in interpreting it as a direction to develop either a federal common law of labor contracts or a more limited federal concept of the nature of the collective bargaining contract, while leaving detailed questions of interpretation to state law, precluded the courts from attributing any substantive content to Section 301 in order to save it from unconstitutionality. Viewed as purely procedural, the section was considered to be outside the Osborn precedent. Although his opinion noted an analogy between federal incorporation and Section 301's vesting of "rights and liabilities, which under state law are distributed among the union members, in a legal 'entity' recognized by federal law for purposes of collective bargaining agreements," 35 Justice Frankfurter thought that the treatment of the union as an entity for this limited purpose was insufficient to sustain the jurisdictional grant. The fact that the validity of the agreement might be contested on federal grounds also failed to provide the necessary federal element. Justice Reed voted to dismiss as a matter of statutory interpretation but thought that the grant of jurisdiction was constitutional. He saw no need to rely upon legislative history because in his view Section 301, by granting jurisdiction over suits

33. 75 Sup. Ct. 488 (1955).

34. Justice Harlan did not participate in the case. Chief Justice Warren and Justice Clark expressly declined to consider the constitutional question.

35. Id. at 495 . 
for violation of collective bargaining agreements; made these violations actionable as a matter of federal law. Although the federal courts might be permitted to apply state law to many issues, this use of state law raises no constitutional problems, for the rules, while derived from state sources, would be applied at the direction and by permission of Congress and thus constitute federal substantive law. Justices Douglas and Black, dissenting from the dismissal, agreed with Justice Reed that the Act "created federal sanctions for collective bargaining agreements, made the cases and controversies concerning them justiciable questions for the federal courts, and permitted the courts to fashion from the federal statute, from state law, or from other germane sources, federal rules for the construction and interpretation of those collective bargaining agreements." 36

Since the Supreme Court divided evenly on the issue of the constitutionality of Section 301 the Westinghouse case serves only to heighten doubts in this respect. It is difficult to see how Justices Frankfurter, Burton and Minton can resolve their doubts in favor of constitutionality so long as they adhere to their conclusion that the section is purely procedural, and consequently the fate of the section hinges upon the positions taken by Chief Justice Warren and Justices Clark and Harlan. Even if the views of Justice Reed should prevail the Westinghouse case furnishes no criterion to guide the lower courts in choosing between state and federally created principles wherever a choice becomes necessary. Thus, both the constitutionality and substantive content of Section 301 remain open questions.

In every lower federal court which has considered the question, the constitutionality of Section 301(a) has been upheld on the ground that the suit which it permits is based upon federally-created substantive law. ${ }^{37}$ These courts, however, have not made a conclusive determination of whether this federal law is an all-inclusive common law, or is merely the principle of contractual enforceability, or is to be garnered from some other portions of the labor statutes. In Waiaula Agricultural Co. v. United Sugar Workers, ILWU, ${ }^{38}$ the court stated that although "Congress did not undertake the task of expressing all the substantive federal law of collective bargaining contracts, it is now in the course of declaration by the courts, on the premise that Congress did impose federal liability." 39 The

36. $I d$. at 503 .

37. United Elec. Workers v. Oliver Corp., 205 F.2d 376 (8th Cir. 1953) ; Hamilton Foundry \& Machine Co. v. International Molders Workers, AFL, 193 F.2d 209 (6th Cir. 1951), cert. denied, 343 U.S. 966 (1952); International Plainfield Motor Co. v. Local 343, United Automobile Workers, CIO, 123 F. Supp. 683 (D.N.J. 1954); Waiaula Agricultural Co. v. United Sugar Workers, ILWU, 114 F. Supp. 243 (D. Hawaii 1953); Ludlow Mfg. \& Sales Co. v. Textile Workers, CIO, 108 F. Supp. 45 (D. Del. 1952); Wilson \& Co. v. United Packing House Workers, CIO, 83 F. Supp. 162 (S.D.N.Y. 1949); Colonial Hardwood Floor Co. v. United Furniture Workers, 76 F. Supp. 493 (D. Md. 1948), affd, 168 F.2d 33 (4th Cir. 1948).

38. 114 F. Supp. 243 (D. Hawaii 1953); see also International Longshoremen's Ass'n v. Libby, McNeill \& Libby, 114 F. Supp. 249, 250 (D. Hawaii 1953).

39. Waiaula Agricultural Co. v. United Sugar Workers, ILWU, 114 F. Supp. 243, 246 (D. Hawaii 1953). 
language of Wilson \& Co. v. United Packing House Workers, CIO, ${ }^{40}$ on the other hand, is more consistent with the view that the intended substantive law was only the principle of enforceability. ${ }^{41}$ Two other courts apparently relied upon some other portions of the Act as the source of the federal right. ${ }^{42}$ The decisions in cases where constitutionality was not discussed also fail to delineate clearly the extent and the basis of the substantive content of Section 301, and there are decisions and dicta in support of each point of view. In Shirley-Herman Co. v. International Hod Carriers ${ }^{43}$ the court upheld a refusal to charge in accordance with the state law requirement that bad faith be shown, stating that a federal substantive remedy had been created to which state law was inapplicable; and in International Union of Operating Engineers v. Dahlem Construction Co. ${ }^{44}$ the court applied a federal rule on the duration of contracts terminable at will, after refusing to rely upon the state rule. However, the chosen federal rule was identical to that of the state. Both of these cases indicate reliance upon a broad construction of 301 as the source of a complete body of federal law, since enforceability alone would not preclude the application of state law to these issues.

Other courts take the position that a substantive right has been created, but they give no indication of the extent of that right.45 Schatte v. International Alliance ${ }^{46}$ held that the section was inapplicable to a breach occurring before its effective date because it created "a new substantive liability actionable in the federal courts" ; ${ }^{47}$ but the language of the case is inconclusive as to whether the court was adopting the federal common law or the enforceability interpretation. Either theory would prevent retro-

40. 83 F. Supp. 162 (S.D.N.Y. 1949).

41. ". . . Congress recognized and regarded the observance and enforcement of such contracts as a matter of federal concern incident to the regulation of commerce, and intended to create a right in each of the parties to such contracts to the observance and the performance thereof by the other. Section $301(\mathrm{a})$. . . would be meaningless on any other hypothesis. ..."Id. at 165.

42. Hamilton Foundry \& Machine Co. v. International Molders Workers, AFL, 193 F.2d 209, 214 (6th Cir. 1951), cert. denied, 343 U.S. 966 (1952) (treating the contract as one recognized by the act, even though an oral one, the cause of action upon it arises out of a law of the United States); Ludlow Mfg. \& Sales Co. v. Textile Workers, CIO, 108 F. Supp. 45, 48 (D. Del. 1952) ("... the whole tenor of the cited act created important substantive rights. . .); cf. United Elec. Workers v. Oliver Corp., 205 F.2d 376, 384-85 (8th Cir. 1953).

43. 182 F.2d 806 (2d Cir. 1950).

44. 193 F.2d 470 (6th Cir. 1951).

45. Association of Westinghouse Salaried Employees v. Westinghouse Elec. Corp., 210 F.2d 623, 625 (3d Cir. 1954), aff'd, 75 Sup. Ct. 488 (1955); Food \& Service Trades Council v. Retail Associates, Inc., 115 F. Supp. 221, 224 (N.D. Ohio 1953) ; Pepper \& Potter Inc. v. Local 977, United Automobile Workers, CIO, 103 F. Supp. 684, 686 (S.D.N.Y. 1952) ; Local 793, United Automobile Workers, CIO v. Auto Specialties Mfg. Co., 15 F.R.D. 261, 263-64 (W.D. Mich. 1951).

46. 182 F.2d 158 (9th Cir.), cert. denied, 340 U.S. 827 (1950); see Studio Carpenters' Union v. Loew's, Inc., 182 F.2d 168, 169 (9th Cir.), cert. denied, 340 U.S. 828 (1950).

47. Schatte v. International Alliance, supra note 46, at 164 ; cf. Boeing Airplane Co. v. Aeronautical Int'l Ass'n of Machinists, 188 F.2d 356 (9th Cir. 1951) (incorporated, by reference, lower court opinion, 91 F. Supp. 596 (W.D. Wash. 1950), which had held on the basis of state law). 
active application of the section, while a merely procedural approach would not. The Tenth Circuit on the other hand, in declining to order further arbitration on the ground that the parties had not requested it, stated that the section is jurisdictional only and "does not give the federal courts any different or additional power than a state court would have if the actions had been brought there." 48 Still others have expressed doubt as to whether a federal or state substantive law should control a particular issue, and have avoided a resolution of the problem by stating that the issue would be similarly decided under both ${ }^{48}$ or that the issue involved was remedial only. ${ }^{50}$

It appears from decisions in both the Ninth and the Third Circuits that those courts will limit the scope of the federal law. The Ninth Circuit, in Boeing Airplane Co.v. Aeronautical Int'l Ass'n of Machinists, ${ }^{51}$ adopted a lower court opinion ${ }^{52}$ which held a contract rescinded in express reliance upon state law and the Erie ${ }^{53}$ doctrine. This same court, in Loew's, Inc., ${ }^{54}$ had held previously that a federal substantive right was created, but the conflict between that reasoning and the application of the Erie doctrine in the later case was ignored. In a series of cases, the Third Circuit assumed without discussion that state law controlled the issue of termination, ${ }^{55}$ later expressed doubt but avoided decision by stating that federal and state law were the same, ${ }^{56}$ and still later, sitting en banc, stated that a federal substantive right was created. ${ }^{57}$ If these cases in the same courts can be said to be consistent with one another it is only on the theory that state law is to govern the incidents of the contract, which is to be made binding as a matter of federal right. Neither circuit, however, has attempted to rationalize its decisions on any particular theory, and it is possible that a broader approach might be adopted in future cases.

There are some indications that as factual situations recur they will be decided in reliance upon similar cases under Section 301(a), and that in this way the federal law adopted will control the disposition of cases to the

48. Mercury Oil Refining Co. v. Oil Workers, CIO, 187 F.2d 980, 983 (10th Cir. 1951).

49. Isbrandtsen Co. v. Local 1291, International Longshoremen's Ass'n, 204 F.2d 495, 498-99 (3rd Cir. 1953).

50. Textile Workers, CIO v. Arista Mills Co., 193 F.2d 529, 533 (4th Cir. 1951); Textile Workers, CIO v. American Thread Co., 113 F. Supp. 137 (D. Mass. 1953);

Hamilton Foundry \& Machine Co. v. International Molders Workers, AFL, 193 F.2d 209, 215 (6th Cir. 1951), cert. denied, 343 U.S. 966 (1952) (Alternative holding). 51. 188 F.2d 356 (9th Cir. 1951).

52. 91 F. Supp. 596, 614 (W.D. Wash. 1950).

53. Erie R.R. v. Tompkins, 304 U.S. 64 (1938).

54. Studio Carpenters' Union v. Loew's, Inc., 182 F.2d 168 (9th Cir.), cert. denied, 340 U.S. 828 (1950).

55. See Patterson Parchment Paper Co. v. International Brotherhood of Paper Makers, 191 F.2d 252, 253 (3d Cir. 1951) ; cf. Insurance Agents' Int'1 Union AFL v. Prudential Ins. Co., 122 F. Supp. 869, 872 (E.D. Pa. 1954).

56. Isbrandtsen Co. v. Local 1291 Int'l Longshoremen's Ass'n, 204 F.2d 495, 498-99 (3d Cir. 1953).

57. Association of Westinghouse Salaried Employees v. Westinghouse Elec. Corp., 210 F.2d 623, 625 (3d Cir. 1954), aff'd, 75 Sup. Ct. 488 (1955). 
exclusion of state law. Such a trend appears to be developing in the frequent cases under Section 301 (a) involving the interpretation of the scope of arbitration clauses, which are quite similar in phraseology. ${ }^{58}$ As other factual situations are presented against a background of similar cases they too might be decided on the basis of federal case law. However, no significant change has been effected in the area of more general legal principles, except for those cases which have used the section to avoid dependence upon the Arbitration Act ${ }^{59}$ in granting specific performance of arbitration agreements. ${ }^{60}$ A choice of state versus federal law seldom has been a determining factor, and thus a broad construction of the substantive content of the section has not been utilized to develop a federal case law which is noticeably divergent from state law.

Most of the cases decided under Section 301 (a) have produced a result which is consistent with that intended by the legislature. Congress went no further than to make collective bargaining agreements legally binding, and most courts have not expanded this intent into the creation of novel rights unforeseen by the legislators; substantive content has been incorporated in the section only to the extent necessary to sustain its constitutionality. By limiting the substantive content, the courts have refused to take advantage of an opportunity to develop an applicable federal concept which would be more closely related to the functions of collective bargaining than those of ordinary contracts. ${ }^{61}$ Nevertheless, reliance upon the meaning attributed to similar factual situations in other federal decisions preserves some degree of uniformity within the federal courts, and statements of the creation of substantive law will enable a court to avoid the effect of state doctrines which are serious obstacles to enforcement. So long as the substantive content is thus limited, treatment of Section 301(a) as a partly substantive law is justified by the legislative history and serves to insure the constitutionality of the jurisdictional grant.

\section{The Impact of Section 301(a) Upon the Enforcement of Arbitration Clauses}

Arbitration clauses in collective bargaining agreements become an issue in suits under Section 301(a) in a variety of ways, each of which presents

58. See Hoover Motor Express Co. v. Teamsters Union, AFL, 217 F.2d 49, 53 (6th Cir. 1954) ; United Elec. Workers v. Oliver Corp., 205 F.2d 376, 384-85 (8th Cir. 1953) ; Markel Elec. Products, Inc. v. United Elec. Workers, 202 F.2d 435, 437 (2d Cir. 1953); Square D Co. v. United Elec. Workers, 123 F. Supp. 776, 782 (E.D. Mich. 1954); Harris Hub Bed \& Spring Co. v. United Elec. Workers, 121 F. Supp. 40, 42 (M.D. Pa. 1954); Metal Polishers Union, AFL v. Rubin, 85 F. Supp. 363, 364 (E.D. Pa. 1949). But cf. Insurance Agents' Int'1 Union, AFL v. Prudential Ins. Co., 122 F. Supp. 869, 872 (E.D. Pa. 1954); Industrial Trades Union v. Woonsocket Dyeing Co., 122 F. Supp. 872, 874 (D.R.I. 1954).

59. 9 U.S.C. $\S \$ 1-15$ (1952).

60. See text at notes 100-07, 114-18, infra.

61. For a discussion of the applicability of contract concepts to collective bargaining agreements see GREGORX, LABOR AND THE LAW 381-84 (1946); Warns, The Nature of the Collective Bargaining Agreement, 3 Mramr L.Q. 235, 250 (1949); Rice, Collective Labor Agreements in American Law, 44 HARv. L. REv. 572, 606-07

(1931). 
different problems. A clause may be interposed defensively in a suit for damages by a motion to stay proceedings pending arbitration; ${ }^{62}$ or it may form the basis of an action for enforcement, such as a suit seeking an order compelling submission of an issue to arbitration, ${ }^{63}$ enforcement of an arbitration award, ${ }^{64}$ or an award of damages for a breach. ${ }^{65}$ Defendants also may set up a plaintiff's prior breach of the clause as a bar to recovery for defendants' subsequent breach of other parts of the agreement. ${ }^{66}$

Specific statutory authority for granting a stay pending arbitration is available under some interpretations of the United States Arbitration Act. ${ }^{67}$ These courts include collective bargaining agreements within the Act and therefore can rule upon the merits of the motion without reference to Section 301(a). Conflicts in applying the Arbitration Act arise from different interpretations of the last clause of Section 1 and Section 3. Section 1, after defining "maritime transactions" and "commerce," concludes with the words "but nothing herein contained shall apply to contracts of employment of seamen, railroad employees, or any other class of workers engaged in foreign or interstate commerce," ${ }^{88}$; Section 3 provides that a stay of proceedings pending arbitration shall be granted in "any suit or proceeding . . . upon any issue referrable to arbitration under an agreement in writing for such arbitration." 69 All the circuits which have ruled on the matter are now in agreement that the "contracts of employment" exclusion applies to the entire Act, but here the unanimity ends. The Fourth Circuit holds

62. Hoover Motor Express Co. v. Teamsters Union, AFL, 217 F.2d 49 (6th Cir. 1954); United Elec. Workers v. Miller Metal Products, Inc., 215 F.2d 221 (4th Cir. 1954); Tenney Engineering, Inc. v. United Elec. Workers, 207 F.2d 450 (3d Cir. 1953); Markel Elec. Products, Inc. v. United Elec. Workers, 202 F.2d 435 (2d Cir. 1953) ; Harris Hub Bed \& Spring Co. v. United Elec. Workers, 121 F. Supp. 40 (M.D. Pa 1954); Ludlow Mfg. \& Sales Co. v. Textile Workers Union, CIO, 108 F. Supp. 45 (D. Del. 1952) ; Boston \& Maine Transp. Co. v. Amalgamated Ass'n, 106 F. Supp. 334 (D. Mass. 1952) ; Lewittes \& Sons v. United Furniture Workers, CIO, 95 F. Supp. 851 (S.D.N.Y. 1951); Metal Polishers, AFL v. Rubin, 85 F. Supp. 363 (E.D. Pa. 1949).

63. Insurance Agents' Int'l Union, AFL v. Prudential Ins. Co., 122 F. Supp. 869 (E.D. Pa. 1954); Industrial Trades Union v. Woonsocket Dyeing Co., 122 F. Supp. 872 (D.R.I. 1954); Local 379, United Automobile Workers, CIO v. Jacobs Mfg. Co., 120 F. Supp. 228 (D. Conn. 1953); Local 207, United Elec. Workers v. Landers, Frary \& Clark, 119 F. Supp. 877 (D. Conn. 1954); Textile Workers Únion, CIO v. Aleo Mfg. Co., 94 F. Supp. 626 (M.D.N.C. 1950). Specific enforcement may also be obtained by way of a counterclaim in an action for damages. Evening Star Newspaper Co. v. Columbia Typographical Union, 124 F. Supp. 322 (D.D.C. 1954).

64. Milk \& Ice Cream Drivers Union v. Gillespie Milk Products Corp., 203 F.2d 650 (6th Cir. 1953); Mercury Oil Refining Co. v. Oil Workers Int'l Union, 187 F.2d 980 (10th Cir. 1951), affirming in part and reversing in part, 89 F. Supp. 702 (W.D. Okla. 1950).

65. While no suits for damages for refusal to arbitrate have been reported, there seems to be nothing other than inability to establish damages which would prevent such a suit. At common law, damages for breach of such an agreement are nominal only. See Restatement, Contracts $\$ 550$ (1932); Arbitration of Labor Disputes, 43 ILL. L. REv. 678, 680 (1948).

66. United Elec. Workers v. Oliver Corp., 205 F.2d 376, 385 (8th Cir. 1953).

67. 9 U.S.C. $\$ 1$ (1952). See text at notes 73-76 infra.

68. 9 U.S.C. $\$ 1$ (1952) (italics added).

69. 9 U.S.C. $\$ 3$ (1952) (italics added).. 
that collective bargaining agreements are within the exclusion and therefore will not grant a stay. ${ }^{70}$ The Third Circuit first held that the exclusion clause was not a limitation upon Section $3,^{71}$ later held that the exclusion clause prevented a stay, ${ }^{72}$ and now takes the position that the exclusion, while it limits Section 3, excludes only the agreements of workers directly engaged in commerce and not those of workers merely engaged in the production of goods for commerce. ${ }^{73}$ The Sixth Circuit in 1942 held that the Act did not apply to a suit by an individual employee for wages due, ${ }^{74}$ but in 1954 the court held that the exclusion clause did not prevent the application of the Act in a suit against a union for violation of a no-strike clause. ${ }^{75}$ The court distinguished the earlier case by saying that the individual hiring contract was clearly a "contract of employment," but that the collective bargaining contract in the later case was a "trade agreement" and therefore outside the exclusion. ${ }^{76}$ This Circuit would therefore grant a stay in suits for violation of the general provisions of the contract, and deny a stay in a suit by an employee. It seems probable that this court will also deny a stay where the union brings the suit on behalf of the individual employee. ${ }^{77}$

Other circuits have been noncommital. Although the Tenth Circuit has not considered the effect of the exclusion clause in stay proceedings, the court stated that the Arbitration Act was inapplicable in holding an arbitration award invalid, ${ }^{78}$ citing two cases which held that the exclusion clause

70. United Elec. Workers v. Miller Metal Products, 215 F.2d 221 (4th Cir. 1954); International Union, United Furniture Workers v. Colonial Hardwood Flooring Co., 168 F.2d 33 (4th Cir. 1948).

71. Watkins v. Hudson Coal Co., 151 F.2d 311 (3d Cir. 1945), cert. devied, 327 U.S. 777 (1946); Donahue v. Susquehanna Collieries Co., 160 F.2d 661 (3d Cir. 1947); Evans v. Hudson Coal Co., 165 F.2d 970 (3d Cir. 1948).

72. Pennsylvania Greyhound Lines, Inc. v. Amalgamated Ass'n of Street Employees, 193 F.2d 327 (3d Cir. 1952) ; Amálgamated Ass'n of Street Employees v. Pennsylvania Greyhound Lines, Inc., 192 F.2d 310 (3d Cir. 1951). 1953).

73. Tenney Engineering, Inc. v. United Elec. Workers, 207 F.2d 450 (3d Cir.

74. Gatliff Coal Co. v. Cox, 142 F.2d 876 (6th Cir. 1944).

75. Hoover Motor Express Co. v. Teamsters Union, AFL 217 F.2d 49 (6th Cir. 1954).

76. Id. at 52. Although the earlier case had been relied upon by other circuits as holding that collective bargaining agreements were within the exclusion, see, e.g., Amalgamated Ass'n of Street Employees v. Pennsylvania Greyhound Lines, Inc., 192 F.2d 310 (3d Cir. 1951); International Union, United Furniture Workers v. Colonial Hardwood Flooring Co., 168 F.2d 33 (4th Cir. 1948), the Hoover court says of these cases: "We think these misconstrue the Gatliff holding." Hoover Motor Express Co. v. Teamsters Union, AFL supra at 52.

77. Cf. Association of Westinghouse Salaried Employees v. Westinghouse Elec. Carp., 210 F.2d 623 (3d Cir. 1954), aff'd, 75 Sup. Ct. 488 (1955). Although it would seem that the suit remains the same no matter whether an employee or a union is the party plaintiff, it is still possible that such a suit will be held to be one on the collective bargaining agreement, for, as pointed out by the Third Circuit, interpretations of the Arbitration Act are based on "policy considerations peculiar to the Arbitration Act. ..." Id. at 626 n.10.

78. Mercury Oil Refining Co. v. Oil Workers Int'l Union, CIO, 187 F.2d 980 , 981 (10th Cir. 1951). 
prevented a stay ${ }^{79}$ and one case holding the exclusion not applicable to stays. ${ }^{80}$ Since no court has applied to labor contracts the Arbitration Act provisions for judicial confirmation of arbitration awards, neither the holding nor the conflicting citations indicate the course which will be taken in a case involving stay proceedings. The Second Circuit, in rejecting a union's contention that a no-strike clause was invalid because it was imbedded in an unenforceable arbitration clause, stated that the Act was inapplicable to collective bargaining agreements. ${ }^{81}$ In a later case the court, while expressly declining to consider the availability of a stay under the Act, denied the stay on the merits; ${ }^{82}$ and one of its district courts has interpreted this case as an indication that the Second Circuit will grant a stay. ${ }^{83}$ In affirming a verdict for the plaintiff, the Eighth Circuit assumed that a stay was available after pointing out that defendant had failed to ask for one. ${ }^{84}$ If the fine distinctions drawn in the Third and Sixth Circuits are any criteria of judicial attitude toward arbitration clauses, it would seem that those circuits which have not yet ruled will grant a stay where, in accordance with Section 3, the issue is an arbitrable one.

Despite the fact that stays are considered remedial, ${ }^{85}$ and therefore are controlled by the law of the forum ${ }^{86}$ even if there is no substantive content to Section 301 (a), those courts which have ruled upon motions for a stay in 301 suits have disposed of the motions without considering whether the Section itself could be construed as containing authorization to grant the stay. In Textile Workers, CIO v. American Thread $\mathrm{Co}^{87}$ the court read 301 (a) as containing an implication of intent to establish specific performance of an agreement to arbitrate as a nationally available remedy, and

79. International Union, United Furniture Workers v. Colonial Hardwood Flooring Co., 168 F.2d 33 (4th Cir. 1948), and the subsequently limited Sixth Circuit Case, Gatliff Coal Co. v. Cox, 142 F.2d 876 (6th Cir. 1942).

80. Watkins v. Hudson Coal Co., 151 F.2d 311 (3d Cir. 1945), cert. denied, 327 U.S. 777 (1946).

81. Shirley-Herman Co. v. International Hod Carriers Union, 182 F.2d 806, 809 (2d Cir. 1950). For this proposition, the court cited International Union, United Furniture Workers v. Colonial Hardwood Flooring Co., 168 F.2d 33 (4th Cir. 1948). See text at note 70 supra.

82. Markel Elec. Products, Inc. v. United Elec. Workers, 202 F.2d 435 (2d Cir. 1953). One district court has granted a stay, Lewittes \& Sons v. United Furniture Workers, CIO, 95 F. Supp. 851 (S.D.N.Y. 1951) (collective bargaining agreement not a "contract of employment"), and another has compelled arbitration by a grant of a preliminary injunction, Textile Workers Union, CIO v. Aleo Mfg. Co., 94 F. Supp. 626 (M.D.N.C. 1950).

83. See Local 207, United Elec. Workers v. Landers, Frary \& Clark, 119 F. Supp. 877, 879 (D. Conn. 1954). 1953).

84. See United Elec. Workers v. Oliver Corp., 205 F.2d 376, 385 (8th Cir.

85. See Textile Workers, CIO v. American Thread Co., 113 F. Supp. 137, 139-42 (D. Mass. 1953); see text at note 87 infra. In Markel Elec. Products, Inc. v. United Elec. Workers, 202 F.2d 435 (2d Cir. 1953), which affirmed a denial of a stay on the merits, Clark, J., dissenting, stated: "An agreement [to arbitrate] cars be enforced without regard to the . . . Arbitration Act." Id. at 438.

86. Donahue v. Susquehanna Collieries Co., 138 F.2d 3, 6 (3d Cir. 1943); Agostini Bros.' Bldg. Corp. v. United States, 142 F.2d 854, 856 (4th Cir. 1944). See Comment, 102 U. of PA. L. Rev. 558, 560 (1954).

87. 113 F. Supp. 137 (D. Mass. 1953). 
this theory would at least arguably support a grant of a stay without specific statutory authority. Any intent read into Section 301 would be equally present where the arbitration clause is used defensively rather than offensively. In addition, there can be no valid ground for denying a stay where the defendant can accomplish the same result by a counterclaim for an order compelling arbitration. ${ }^{88}$

It is impossible to state with any degree of certainty why, in the light of the American Thread reasoning, consideration of the availability of authority to grant the stay has still been confined to the Arbitration Act; but several possible explanations can be advanced. With the interpretation of the Arbitration Act in a state of flux, it is easier to expand its coverage than to adopt a theory which relies upon an intent which is conceded to have only meager support from the legislative history. ${ }^{89}$ The vacillations of the Third ${ }^{90}$ and Sixth Circuits ${ }^{91}$ amply demonstrate this proposition. The Third Circuit in its latest case recognized American Thread as a "well considered" opinion, but stated that its own conclusion that Section 3 was available made it unnecessary to consider whether the defendant would have been entitled to a stay under Section 301(a).$^{92}$ Those cases which denied a stay after American Thread involved arbitration clauses which the courts considered inapplicable to the issue tried, ${ }^{93}$ and consequently there was no necessity to explore the possibility of finding some authority to grant the stay. In addition, most movants rely solely upon Section 3 , and courts naturally deny the stay after holding that Section 3 does not apply ${ }^{94}$ without ruling upon arguments which the movant did not make. The Fourth Circuit, in reaffirming its position that Section 3 does not authorize a stay, both expressly restricted its discussion to the Arbitration Act and held the issue not arbitrable. ${ }^{95}$ The common-law rule would preclude granting a stay, ${ }^{96}$ and therefore these courts are justified in requiring some statutory

88. Evening Star Newspaper Co. v. Columbia Typographical Union, 124 F. Supp. 322 (D.D.C. 1954).

89. See Textile Workers, CIO v. American Thread Co., 113 F. Supp. 137, 141

(D. Mass. 1953).

90. See text at notes 71-73 supra.

91. See text at notes 74-77 supra.

92. Tenney Engineering, Inc. v. United Elec. Workers, 207 F.2d 450, 454 (3d Cir. 1954).

93. United Elec. Workers v. Miller Metal Products, Inc., 215 F.2d 221, 224 (4th Cir. 1954); Square D Co. v. United Elec. Workers, 123 F. Supp. 776, 782 (E.D. Mich. 1954).

94. Ludlow Mfg. \& Sale Co. v. Textile Workers, CIO, 108 F. Supp. 45 (D. Del. 1952); Boston \& Maine Transp. Co. v. Amalgamated Ass'n of Street Employees, 106 F. Supp. 334 (D. Mass. 1952) ; cf. International Union, United Furniture Workers v. Colonial Hardwood Flooring Co., $168 \mathrm{~F} .2 \mathrm{~d} 33$ (4th Cir. 1948) (issue not arbitrable); Metal Polishers, AFL v. Rubin, 85 F. Supp. 363 (E.D. Pa. 1949) (issue not arbitrable).

95. United Elec. Workers v. Miller Metal Products, Inc., 215 F.2d 221, 224 (4th Cir. 1954).

96. One of the corollaries of the common-law doctrine of revocability is the rule that the bringing of the suit without resort to arbitration constitutes a revocation by act. See Sturges \& Murphy, Some Confusing Matters Relating to Arbitration inder the United States Arbitration Act, 17 LAw \& CoNTEMP. ProB. 580, 581 n.2 (1952) ; Simpson, Specific Enforcement of Arbitration Contracts, 83 U. of PA. L. REV. 160, 162 (1934). 
authority to reverse the rule; but since they did not consider the possibility that Section 301(a) might supply this authority they do not support the proposition that such authority cannot be found there. The question must therefore be treated as an open one, and its answer will depend upon much the same factors as determine the specific enforceability of arbitration agreements. In view of the readiness of the courts to compel arbitration ${ }^{97}$ and expand the coverage of Section 3, it appears that reliance upon Section 301(a) where the Arbitration Act is not available would not be misplaced.

The questions presented when a party to a collective bargaining agreement seeks to compel the other to submit an issue to arbitration in accordance with the terms of the agreement differ from those presented by a motion for a stay in two important respects: the Arbitration Act is not available, and the strictures of the Norris-LaGuardia Act ${ }^{98}$ must be avoided. The Arbitration Act cannot be relied upon because Section 4, which provides for an order to compel arbitration, is limited to those cases which are included within Section 2,99 whereas Section 3 is not; it is therefore necessary to look elsewhere for a basis of enforceability. This form of relief also encounters the restrictions on the issuance of injunctions while a stay does not.

Textile Workers, CIO v. American Thread Co., ${ }^{100}$ the leading case holding that specific enforcement of an agreement to arbitrate is available under Section 301(a), furnishes a convenient basis for discussion of these two problems. After avoiding a choice between state and federal law on the theory that an agreement to arbitrate, although revocable and unenforceable, was valid under both, Judge Wyzanski held that specific enforcement was remedial, and that Section 301(a) contemplated that the remedies of the parties should be determined by federal law and should include the remedy of specific enforcement. The characterization of the specific enforcement aspect as remedial, while well substantiated by similar. holdings in a variety of situations, ${ }^{101}$ avoids a determination of the substantive content of 301 but does not obviate the necessity of looking to that section for authority to overturn the common-law rule that executory agreements to arbitrate are not enforceable. ${ }^{102}$ The legislative history is, as

97. See text following note 113 infra.

98. 47 STat. 70 (1932), 29 U.S.C. \$§101-15 (1952).

99. "A written provision in any maritime transaction or a contract evidencing a transaction involving commerce. . " 9 U.S.C. \$2 (1952); Tejas Development Co. v. McGough Bros., 165 F.2d 276 (5th Cir. 1948); Watkins v. Hudson Coal Co., 54 F. Supp. 953 (M.D. Pa. 1944) ; see Shanferoke Coal \& Supply Corp. v. Westchester Service Corp., 70 F.2d 297, 298 (2d Cir. 1934); see Sturges \& Murphy, supra note 96, at 601; Comment, 102 U. of PA. L. REv. 558-60 (1954).

100. 113 F. Supp. 137 (D. Mass. 1953).

101. See Sturges \& Murphy, supra note 96, at 587-98.

102. See, e.g., Restatement, Contracts $\$ 550$ (1932); Sturges \& Murphy, supra note 96, at 581 n.2; Simpson, supra note 96, at 162; Wolaver, The Historical Background of Commercial Arbitration, 83 U. OF PA. L. REv. 132 (1934); Note, Arbitration of Labor Contract Interpretation Disputes, 43 ILL. L. REV. 678, 679-80 (1948). 
elsewhere, less than clear on this point. Sections $8(a)(6)$ and $8(b)(5)$ of the Senate amendment to the original House Bill made it an unfair labor practice for an employer or representative "to violate the terms of a collective bargaining agreement or the terms of an agreement to submit a labor dispute to arbitration;" 103 but the House conference report explains the omission only with the statement that "enforcement of the contract should be left to the usual processes of the law and not of the National Labor Relations Board." 104 Little support can be gained from this statement, since the usual processes of the law did not include specific enforcement, ${ }^{105}$ and since the effect of the omission is to remove the agreement from the Board's broader enforcement powers. If Congress did manifest an intent to make collective bargaining agreements generally enforceable, ${ }^{108}$ it would seem that the arbitration clause should partake of this enforceability. The fact that the amendment treated the collective bargaining agreement and agreements to arbitrate in the same manner indicates that arbitration should be as enforceable as the remainder of the contract in which it is included. The common-law doctrine "rests on merely weak historical arguments" 107 and the passage of Section 301(a) should be sufficient to overturn it.

The Norris-LaGuardia Act is a more formidable barrier. The American Threád case said merely that the Act's structure, purposes and legislative history show that it has no application to an injunction compelling arbitration in accordance with a voluntary agreement; ${ }^{108}$ the court placed special reliance upon Section 8, which bars injunctions to any party "who has failed to make every reasonable effort to settle such disputes either by negotiation . . . or voluntary arbitration." 109 However, this section merely makes resort to voluntary arbitration a condition precedent and does not purport to permit an injunction compelling it. The rejected Senate amendment to the Labor-Management Relations Act clearly recognizes that an order to compel arbitration involved a "labor dispute"; it used the phrase "submission of a labor dispute to arbitration," and "labor dispute" is defined in the LMRA almost exactly as it is in the NorrisLaGuardia Act.110 Despite the fact that a literal interpretation of the Norris-LaGuardia Act would prevent the issuance of an injunction com-

103. H.R. 3020, 80th Cong., 1st Sess. $\S \S 8(a)(6), 8(b)$ (5) (1947).

104. H.R. Rep. No. 510, 80th Cong., 1st Sess. 42 (1947).

105. See note 102 supra. Moreover, this same statement and omission is often relied upon as an indication of an intent not to expand the powers of the courts in suits for injunction.

106. See text at notes 25-32 supra.

107. Textile Workers, CIO v. American Thread Co., 113 F. Supp. 137, 142 (D. Mass. 1953) ; see Kulukundis Shipping Co. v. Amtorg Trading Corp., 126 F.2d 978, 982-85 (2d Cir. 1942); Wolaver, The Historical Backgronnd of Conmercial Arbitration, 83 U. OF PA. L. Rev. 132, 138-42 (1934).

108. 113 F. Supp. 137, 142 (D. Mass. 1953).

109. 47 STAT. 72 (1932), 29 U.S.C. $\$ 108$ (1952).

110. 47 STAT. 72 (1932), 29 U.S.C. \$113(c) (1952). The NLRA definition adds the word "tenure" to the Norris-La Guardia Act's ". . terms or conditions of employment. $" 49$ Stat. 450 (1935), as amended, 61 Stat. 137 (1947), 29 U.S.C. \$152(9) (1952). 
pelling arbitration, ${ }^{111}$ this situation presents the most appealing case for the adoption of a less literal view.112 If arbitration cannot be secured through legal sanctions, a party must either enforce its demands through economic sanctions, or capitulate. Issuance of the order compelling arbitration offers an additional opportunity to avoid resort to strikes and lockouts by providing an alternative peaceful method of securing recognition of the demands. The resultant arbitration award, when coupled with public opinion and the high rate of compliance with arbitrators' decisions, furnishes an additional deterrent to economic action on the part of the loser. The weaker party will be protected, since the availability of the courts will remove the need for capitulation in the face of superior economic strength. Nor does the issuance of the order contravene the Norris-IaGuardia Act's policy of reducing judicial interference in labor relations. Invocation of the courts actually will lessen this interference because the merits of a controversy will be determined by the arbitrator rather than by a judge in any later proceeding where the issue might be litigated. ${ }^{113}$

Other cases decided under Section 301(a) show that there is a strong trend toward permitting specific enforcement of arbitration clauses. The first case so holding ${ }^{114}$ saw no need to discuss the common-law rule of nonenforceability. After rejecting defendant's contention that the state rule applied, the court based its power to enforce the clause on the theory that the relief was available as a federal remedy under Section 301(a). It then avoided the Norris-LaGuardia Act by holding that the Act was not applicable in suits against employers. ${ }^{115}$ Later cases have ordered arbitration either without discussing the effect of the Norris-LaGuardia Act ${ }^{116}$ or in reliance upon American Thread.117 In Local 207, United Elec. Workers $v$. Landers, Frary $\&$ Clark 118 the court weighed the desirability of arbitration in place of economic sanctions, the Norris-La-Guardia policy

111. The courts assume that an order compelling arbitration is an injunction within the meaning of the Norris-LaGuardia Act. See, e.g., Textile Workers, CIO v. Aleo Mfg. Co., 94 F. Supp. 626, 629 (M.D.N.C. 1950). The Act prohibits a "restraining order or temporary or permanent injunction. . " 47 STAT. 70, 72 (1932), 29 U.S.C. $\$ \$ 101,104,108$ (1952). Specific enforcement of contracts is treated as injunctive also.

112. See Comment, The Specific Enforcenent of Collective Bargaining Agreements under $\$ 301(a)$ of the Taft-Hartley Act, 21 U. OF CHI. L. REv. 251, 264 (1954).

113. E.g., as a defense to a suit for damages under $\$ 301$ (a) where the party resorts to economic sanctions to enforce his demands. 1950).

114. Textile Workers, CIO v. Aleo Mfg. Co., 94 F. Supp. 626 (M.D.N.C.

115. This interpretation of the Norris-LaGuardia Act appears to be unwarranted. See Comment, supra note 112, at 263. See text at notes 166-73 infra.

116. Insurance Agents' Int'l Union, AFL v. Prudential Ins. Co., 122 F. Supp. 869 (E.D. Pa. 1954) (enforceable under state law); Local 397, United Automobile Workers, CIO v. Jacobs Mfg. Co., 120 F. Supp. 228 (D. Conn. 1953) (the only issue was whether an arbitrable question was presented).

117. Evening Star Newspaper Co. v. Columbia Typographical Union, $124 \mathrm{~F}$. Supp. 322 (D.D.C. 1954) (by way of a counterclaim) ; cf. Industrial Trades Union v. Woonsocket Dyeing Co., 122 F. Supp. 872 (D.R.I. 1954) (enforcement denied on the merits but power to enforce assumed).

118. 119 F. Supp. 877 (D. Conn. 1954). 
of preventing compulsion and judicial interference, and Section 301(a)'s purpose of increasing the enforceability of collective bargaining agreements, and concluded that it possessed the power to order arbitration. Two circuits have noted that their decisions on a motion for a stay did not preclude the possibility that they might grant specific enforcement, ${ }^{119}$ while a third has indicated agreement with the proposition that such relief would not violate the prohibitions of the Norris-LaGuardia Act. ${ }^{120}$ In view of the district court holdings and the circuit court dicta, it appears that Section 301(a) jurisdiction may be successfully utilized as a method of obtaining the enforcement of an agreement to arbitrate.

If the arbitration clause is relied upon for purposes other than as the basis of a motion for a stay or of a suit to compel arbitration, the result becomes even less predictable. Depending upon the nature of the arbitration award and the form which a noncompliance assumes, it often will be impossible for a court to enforce the award without directly contravening the prohibitions of the Norris-LaGuardia Act. Effective enforcement without some form of injunctive relief can be achieved only if the award is limited to a decision that money is due. ${ }^{121}$ A declaration of the rights of the parties, including a determination of the validity of an award, is available under Section 301 (a) ${ }^{122}$ and the Declaratory Judgment Act, ${ }^{123}$ but this of itself can exert only moral pressure toward acceptance of the award. It may, however, be useful in litigation concerning issues other than validity alone. The declaration is conclusive upon the parties and would thereby provide the defense of a prior breach in a suit for damages against a victorious party who resorts to economic action to enforce compliance with the award, while a declaration of invalidity would preclude such a defense and also enable a party to ignore the award without incurring liability under Section 301(a).

One court has been willing to go so far as to hold the NorrisLaGuardia Act inapplicable in ordering reinstatement of an employee in accordance with an arbitrator's award; ${ }^{124}$ but none has yet enjoined union

119. The Third Circuit, in holding that a stay was available under the Arbitration Act, cited American Thread as a "well considered" opinion. Tenney Engineering, Inc. v. United Elec. Workers, 207 F.2d 450, 454 (3d Cir. 1953). The Fourth Circuit, in denying a stay on the alternating grounds that the issue was not arbitrable and that the Arbitration Act did not apply, expressly limited its decision on the latter point to the Arbitration Act alone, stating: "Nor do we decide that such agreements to arbitrate may not be specifically enforced." United Elec. Workers v. Miller Metal Products, Inc., 215 F.2d 221, 224 (4th Cir. 1954).

120. W. L. Mead, Inc. v. Teamsters Union, AFL, 217 F.2d 6, 9 (1st Cir. 1954). The court held that enjoining of a strike in breach of such an agreement was forbidden, citing the American Thread case for the proposition that equitable relief not contrary to the act was within $\$ 301(\mathrm{a})$. Id. at 9.

121. Cf. United Protective Workers v. Ford Motor Co., 194 F.2d 997 (7th Cir. 1952) (injunction against operation of compulsory retirement plan denied because of adequate remedy at law).

122. See, e.g., Mercury Oil Refining Co. v. Oil Workers Int'l Union, CIO, 187 F.2d 980 (10th Cir. 1951).

123. 28 U.S.C. $\$ \$ 2201,2202$ (1952).

124. Milk \& Ice Cream Drivers Union v. Gillespie Milk Products Corp., 203 F.2d 650 (6th Cir. 1953). 
non-compliance which took the form of a strike to enforce its demands. Issuance of an injunction in the latter case could be justified only on the theory either that any breach of a contract is not a labor dispute or that Section 301(a) has repealed the Norris-LaGuardia Act, for there is no reason to treat non-compliance with an award any differently than other breaches of contract. ${ }^{125}$

In other situations the wording of the clause will determine whether it can be invoked successfully as a defense. Defendants in suits for violation of a no-strike clause usually have been unsuccessful in contending that the suit involves an issue referrable to arbitration. Where the provision is for arbitration of disputes, differences, disagreements, grievances, or other similar terms as the last step in the grievance procedure, the clause is held not to apply to any issue involved in the suit on the theory that the clause covers only those controversies suitable for settlement at the lower levels of the grievance procedure and not claims for damages; ${ }^{128}$ and where the arbitration clause is in juxtaposition to the no-strike clause the former is held inapplicable on the theory that the claim for violation is not arbitrable under a contract designed to prevent the violation. ${ }^{127}$ However, Lerenttes \& Sons v. United Furniture Workers, CIO ${ }^{128}$ demonstrates that an appropriately worded provision can be effectively utilized defensively in a suit for violation of a no-strike clause. In that case the court reasoned that the placement of the clause at the head of the grievance procedure indicated an intent not to limit the clause to grievances, and that the inclusion of the words "disputes arising out of or relating to this agreement, or the breach thereof" 129 indicated an intent that claims for damages be arbitrated rather than litigated.

The above courts approached the problem of the effect of an arbitration clause upon a suit for violation of the contract as a question of whether

125. This proposition is immediately apparent where the arbitrator is confined by the contract to interpreting and applying the terms of the contract; a valid decision is an application of the contract to a particular set of facts, and a refusal to act in conformity with the decision is therefore nothing more than a breach of the terms of the contract itself. Even where the umpire has the power to add to the terms of the contract, it is impossible to draw a line between enforcement of the award and a suit on the contract. This point is illustrated by United Shoe Workers v. Le Danne Footwear, Inc., 83 F. Supp. 714 (D. Mass. 1949), in which the union sued the employer for failure to pay wage increases in accordance with the terms of an oral agreement to accept the award rendered by the state board in a proceeding involving the union and other employers.

126. United Elec. Workers v. Miller Metal Products, Inc., 215 F.2d 221, 223 (4th Cir. 1954); Markel Elec. Products, Inc. v. United Elec. Workers, 202 F.2d 435, 437 (2d Cir. 1953) ; International Union, United Furniture Workers v. Colonial Hardwood Flooring Co., 168 F.2d 33, 35 (4th Cir. 1948); Harris Hub Bed Spring Co. v. United Elec. Workers, 121 F. Supp. 40 (M.D. Pa 1954); see Square D Co. v. United Elec. Workers, 123 F. Supp. 776 (E.D. Mich. 1954); Metal Polishers Union, AFL v. Rubin, 85 F. Supp. 363, 364 (E.D. Pa. 1949) ; cf. Hoover Motor Express Co. v. Teamsters Union, AFL, 217 F.2d 49, 53 (6th Cir. 1954).

127. See International Union, United Furniture Workers v. Colonial Hardwood Flooring Co., 168 F.2d 33, 35 (4th Cir. 1948); Harris Hub Bed Spring Co. v. United Elec. Workers, 121 F. Supp. 40, 42 (M.D. Pa. 1954); Metal Polishers Union, AFL v. Rubin, 85 F. Supp. 363,364 (E.D. Pa. 1949).

128. 95 F. Supp. 851 (S.D.N.Y. 1951).

129. Id. at 854 (italics added). 
or not the claim for relief itself was intended to be arbitrated. This approach is improper because it might in many cases result in the court's making an interpretation, necessary to a decision on the merits of the suit, of an issue which the parties intended should be determined by the arbitrator. The court which refuses to refer the entire suit to arbitration necessarily will have to interpret the no strike clause, for example, to determine whether it is in effect,, 130 whether the strike is "authorized," 131 or whether there has been a prior breach by the employer which might justify the strike. ${ }^{132}$ Where the agreement is to submit to arbitration all questions of interpretation, the court which decides these questions in a suit for damages, and thus refuses to dismiss or stay pending arbitration because the claim for damages is not arbitrable, has undertaken to interpret the contract and thereby replace the arbitrator.

The effect of the arbitration clause is also important where the union defends on the theory that the employer's refusal to arbitrate is a breach which excuses what would otherwise be a violation of the no-strike obligation. Whether this defense should be upheld as a matter of the federal law of labor contracts may well depend upon whether an order compelling arbitration is available to the union as an alternative method of enforcing its demands. If the order can be had a court might require that this step be taken before the strike is called; if an order is unavailable, the strike is the only way in which the union can secure the employer's compliance. Whether the terms of the contract restrict the no-strike clause to unprovoked strikes will depend upon the interpretation of that clause, which under the assumed arbitration clause is to be determined by the arbitrator. Where, on the other hand, the union has failed or refused to arbitrate the meaning of the arbitration provision, the validity of the union's demands under a correct interpretation of the contract are not involved. Under these circumstances the merits of the controversy which precipitated the breach are irrelevant in the suit for damages. ${ }^{133}$ Since the extent to which it is the

130. See, e.g., Ludlow Mfg. \& Sales Co. v. Textile Workers Union, CIO, 108 F. Supp. 45 (D. Del. 1952), in which the court rejected the union's contention that the contract, which contained a reopening clause suspending the no-strike obligation, permitted a strike before the expiration of the 30-day period after the opening. The court, after denying a motion for a stay, interpreted the contract as precluding strikes until after 30 days. Id. at 50. See also Markel Elec. Products, Inc. v. United Elec. Workers, 202 F.2d 435 (2d Cir. 1953).

131. See, e.g., Square D Co. v. United Elec. Workers, 123 F. Supp. 776 (E.D. Mich. 1954), in which the court, interpreting the arbitration clause as including only employee grievances, stated that even if the paragraph making arbitration the exclusive remedy for violations referred to in the preceding section, which absolved the union from liability for unauthorized strikes, there was no arbitrable issue because the complaint alleged an authorized strike. Id. at 783 .

132. See, e.g., Morrison v. Local 682, Int'l Ass'n of Bridge Workers, AFL, 114 F. Supp. 54 (W.D. Ky. 1953), in which the court issued a judgment declaring that a certain person was not an "employee" within the meaning of the contract. The company had refused to arbitrate the union demand that as an employee he was required to pay dues, and the union struck. The court did not even discuss the effect of the arbitration clause or the plaintiff's refusal to arbitrate. The company's suit for an injunction against the strike was remanded to the state court. Id. at 55 .

133. Shirley-Herman Co. v. International Hod Carriers Union, 182 F.2d 806 (2d Cir. 1950). 
proper function of a court to interpret the contract in a 301 suit will be controlled by the contract, the parties should take care to express their intent if they desire that this function be performed by an arbitrator. This can be accomplished either by proper wording of the arbitration clause, in which case some risk is run that a particular court might avoid their desires by holding that the arbitration act stay provisions are inapplicable, or by restricting the no-strike clause itself so that a determination by an arbitrator that a breach has occurred is a condition precedent to liability for damages. Section 301(a), in increasing the possibility that one of the parties will be subjected to liability for its breaches under a court's interpretation of the contract, makes these problems more worthy of attention during the negotiation of the contract.

\section{Available Relief}

The language of Section 301(a) does not set any limits on the type of relief which the district courts can render in "suits for violation of contracts." 184 Both the use of the unlimited word "suits" and a comparison with Section 303(b), which limits recovery for violation of the secondary boycott provisions to the damages sustained, ${ }^{135}$ show that the broader language of Section 301(a) comprehends more than just suits for money judgments. No court has doubted that the grant includes jurisdiction over suits for damages, and suits for declaratory ${ }^{136}$ and injunctive ${ }^{137}$ relief frequently have been entertained. Of the decisions refusing to take jurisdiction of suits for equitable relief, all but one have been predicated upon the existence of restrictions found elsewhere, ${ }^{138}$ rather than upon any deficiency in the jurisdictional grant. Thus, the courts have indicated that Section 301(a) itself contains no limitations upon the types of relief which may be obtained in the suits which it permits.

The sole case to the contrary is International Longshoremen's Union v. Libby, McNeill \& Libby, ${ }^{139}$ which dismissed a union's suit for an in-

134. Compare H.R. 3020, 80th Cong., 1st Sess. \$302(a) (1947). "Any action for or proceeding involving a violation..." The difference in language between this original House Bill and the Act as passed is not commented upon, and it would therefore appear that no substantial change was either intended or effected.

135. "Whoever shall be injured in his business or property . . . may sue therefor in any district court of the United States ... and shall recover the damages by him sustained and the cost of the suit." 61 STAT. 159 (1947), 29 U.S.C. § $187(\mathrm{~b})$ (1952).

136. AFL v. Western Union Tel. Co., 179 F.2d 535 (6th Cir. 1950) ; Morrison v. Shopmen's Union, AFL, 114 F. Supp. 54 (W.D. Ky. 1953) ; Studio Carpenters Union v. Loew's, Inc., 84 F. Supp. 675 (S.D. Cal. 1949); see United Protective Workers v. Ford Motor Co., 194 F.2d 997, 1000 (7th Cir. 1952). Other courts have taken jurisdiction over suits for declaratory judgment without commenting upon the declaratory relief requested. See, e.g., Modine Mfg. Co. v. Grand Lodge Int'l Ass'n of Machinists, 216 F.2d 326 (6th Cir. 1954); Textile Workers, CIO v. Arista Mills Co., 193 F.2d 529 (4th Cir. 1951); United Steel Workers, CIO v. Shakespeare Co., 84 F. Supp. 267 (W.D. Mich. 1949).

137. See cases cited notes $159-71$ infra.

138. Either by the Norris-LaGuardia Act or by $\$ 10$ (a) of the NLRA, 61 STAT. 146 (1947), 29 U.S.C. $\$ 160$ (a) (1952) (giving the NLRB jurisdiction over unfair labor practices).

139. 114 F. Supp. 249 (D. Hawaii 1953). 
junction and a declaration of the rights of the parties under the contract and, on petition for a new trial, ${ }^{140}$ held that Section 301(a) conferred no jurisdiction over the suit for declaratory relief alone. For support of its basic proposition that the section includes only suits for damages, the court relied upon its opinion in a prior case, ${ }^{141}$ which remanded an employer's suit for an injunction against a strike in breach of the contract. The prior opinion held that Section 301(a) had not repealed the NorrisLaGuardia Act because congressional attention had been centered upon money judgments. As part of its argument, the court cited three factors: the lifting of the jurisdictional amount requirement, the 301 (b) provision limiting the effect of judgments against the union entity, and statements of senatorial solicitude for the individual union member. ${ }^{142}$ However, these factors do not support the denial of declaratory relief in the more recent case. The elimination of the jurisdictional amount requirement applies to every kind of suit otherwise permitted, and thus is irrelevant to the issue of what relief is available. The limitation upon the effect of money judgments and the statements pointing out the nonliability of the individual are both natural concomitants of treating labor unions as incorporated bodies; and, since a suit for damages was among those permitted, a specific provision was necessary to prevent the result in the Danbury Hatters' cases, ${ }^{143}$ in which individual union members were subjected to heavy financial liability. Moreover, the fact that Congress failed to advert to other types of relief leads to opposite conclusions in regard to injunctions and declaratory judgments. The passage of a broadly phrased jurisdictional grant in the presence of a statutory prohibition of certain types of injunctions indicates that the prohibition remains unrepealed, while such a grant in the presence of statutory allowance of

140. 115 F. Supp. 123 (D. Hawaii 1953).

141. Castle \& Cooke Terminals v. Local 137, Int'l Longshoremen's Union, 110 F. Supp. 247 (D. Hawaii 1953).

142. Senator Taft: "But the pending bill provides they can be sued as if they were corporations and if a judgment is found against the labor organization, even though it is an unincorporated association, the liability is on the labor union and the labor-union funds, and it is not on the individual members of the union, where it has fallen in some famous cases to the great financial distress of the individual members of labor unions." 93 CoNG. Rec. 3955 (1947). Senator Smith: "[Title III] requires that labor organizations, as well as employers, shall be responsible for carrying out contracts legally, entered into as the result of collective bargaining." After quoting Justice Brandeis' statement that unions should make themselves amenable to law, Senator Smith continued "I cannot see how anyone can take issue with ... [that] statement . . . or ... with the provisions of title III, which simply carry out the idea, by providing that whichever side is guilty of violating a contract solemenly entered into shall be responsible for damages resulting from such violation." 93 CoNG. REc. 4410 (1947). Senator Ball, arguing that the bill benefited employees, stated that employers already had a right to sue unions subject to procedural difficulties, "and, if a judgment is rendered, it holds every member liable for the judgment.

"The pending measure, by providing that the union may sue and be sued as a legal entity, for a violation of contract, and that liability for damages will lie against union assets only, will prevent a repetition of the Danbury Hatters case. . . ." 93 Cong. Rec. 5146 (1947). (1915).

143. Loewe v. Lawlor, 208 U.S. 274 (1908); Lawlor v. Loewe, 235 U.S. 522 
declaratory relief ${ }^{144}$ indicates that the latter is available. The conclusion of the Libby court therefore must bow to the weight of authority and to the reasoning of Studio Carpenters Union v. Loew's, Inc.: ${ }^{145}$

"Had Congress intended that the suits authorized by Sec. 301 should have been only suits for damages, it would have been a simple thing to have included that word in the language of the Section. There is no doubt that the language used in Sec. 301 includes suits for damages, but does not exclude a suit for declaratory relief . . .."

Most of the cases which have raised the question of available relief under 301 (a) concern suits for an injunction against breach of the contract. The answer depends upon the applicability of the NorrisLaGuardia Act, which deprives the federal courts of jurisdiction to enjoin several enumerated types of conduct in cases "involving or growing out of" labor disputes, ${ }^{146}$ and establishes strict prerequisites for an injunction in all other labor dispute cases. ${ }^{147}$ Although state courts and commentators have argued that suits for breach of labor contracts should not be considered within the scope of the Act, ${ }^{148}$ the federal courts have consistently relied upon it to deny injunctions in such suits. ${ }^{149}$ The enactment of Section 301 (a) conceivably might have been held to relieve such injunctions from the Norris-LaGuardia ban on the theory that, since both operate on a jurisdictional level, ${ }^{150}$ the later grant restored the jurisdiction previously withheld. Legislative history, however, compels the opposite conclusion. A provision in the House Bill expressly exempting suits for violation of contract ${ }^{151}$ from the Norris-LaGuardia Act was deleted in

144. 28 U.S.C. $\$ \$ 2201,2202$ (1952).

145. 84 F. Supp. 675,676 (S.D. Cal. 1949).

146. 47 STAT. 70 (1932), 29 U.S.C. \$104 (1952).

147. 47 StAT. 71, 72 (1932), 29 U.S.C. $\$ \$ 107-09$ (1952).

148. See Rice, $A$ Paradox of Our National Labor Law, 34 MarQ. L. Rev. 233 (1951); Note, Specific Performance of Collective Bargaining Agreements, 37 VA. L. Rev. 739 (1951) ; Comment, 21 U. of CHI. L. Rev. 251 (1954).

149. W. L. Mead, Inc. v. International Brotherhood of Teamsters, AFL, 217 F.2d 6 (1st Cir. 1954); In re Third Avenue Transit Corp., 192 F.2d 971 (2d Cir. 1951); Alcoa S.S. Co. v. McMahon, 173 F.2d 567 (2d Cir. 1949), affirming 81 F. Supp. 541 (S.D.N.Y. 1948); Sound Lumber Co. v. Lumber \& Sawmill Workers Union, 122 F. Supp. 925 (N.D. Cal. 1954); Local 937, International Union, United Automobile Workers, CIO v. Royal Typewriter Co., 88 F. Supp. 669 (D. Conn. 1949); Duris v. Phelps Dodge Copper Products Corp., 87 F. Supp. 229 (D.N.J. 1949) ; Colorado-Wyoming Express v. Denver Iocal 13, Int'1 Brotherhood of Teamsters, AFL, 35 F. Supp. 155 (D. Colo. 1940); Wilson \& Co. v. Birl, 27 F. Supp. 915 (E.D. Pa. 1939), aff'd, 105 F.2d 948 (3rd Cir. 1939). The Supreme Court has indicated agreement; see United States v. United Mine Workers, 330 U.S. 258, 270, 312 (1947) ; Milk Wagon Drivers' Union v. Lake Valley Co., 311 U.S. 91, 100-03 (1940), and Congress understood this position to be the law, see SEN. REP. No. 105, 80th Cong., 1st Sess. 17 (1947).

150. See 47 STAT. 70, 71 (1932), 29 U.S.C. $\$ \$ 101,104,105,107$ (1952). Section 101 provides: "No court of the United States .. . shall have jurisdiction to issue any restraining order or temporary or permanent injunction. . ."; 29 U.S.C. $\$ 102$ provides: ". . . in determining the jurisdiction and authority of the courts of the United States... the public policy of the United States is declared as follows. ..."

151. H.R. 3020, 80th Cong., 1st Sess. $\$ 302(\mathrm{e})$ (1947). 
the Senate, as was the Senate provision subjecting such violations to injunction as unfair practices. ${ }^{152}$ Congress thought a mere grant of jurisdiction inappropriate and insufficient to effectuate an exception to the injunction statute, ${ }^{153}$ and in other circumstances where injunctive relief was considered desirable the Norris-LaGuardia Act was expressly made applicable. ${ }^{154}$ Senator Taft assessed the temper of the Senate as being strongly against restoration of the injunction as a weapon in the hands of private parties. ${ }^{155}$ In addition, the canon that repeals by implication are not favored has particular validity when applied to this situation, where "the earlier enactment is a significant and tremendously important piece of legislation which the Congress evidently had specifically in mind ... "156 These factors compel the conclusion that the passage of Section 301 (a) was not intended to reduce in any way the vitality of the NorrisLaGuardia Act, and every court which has considered the opposite contention has rejected it. ${ }^{107}$

Despite the fact that no court has expressly disagreed with these holdings, Section 301(a) has resulted in a relaxation of the restrictions on injunctions by federal holdings that the Act never applied, rather than that 301(a) has rendered it inapplicable. Many courts have taken the occasion presented by a suit under the section to grant injunctive relief even though the case would seem to involve a "labor dispute." This is a tenuous result, however, because violation of any contractual provision

152. S. 1126, 80th Cong., 1st Sess. $\$ 88$ (a) (6), 8(b) (5) (1947).

153. Senator Taft, in discussing a proposed amendment to $\S 303$ which would give federal courts "jurisdiction to prevent and restrain violations" of $\$ 303$ in certain cases, stated: "I really do not think. . . [that] amendment to give jurisdiction, without any reference to the Norris-LaGuardia Act . . . is in any way changing the legal situation of those who are injured under those circumstances." 93 Cong. Rec. 5066 (1947). See also the remarks of Senator Ferguson, id. at 5067.

154. $\$ 10(\mathrm{~h}),(1), 61$ STat. 149 (1947), 29 U.S.C. $\$ \$ 160(\mathrm{~h}),(1)(1952)$ (unfair practices); §208(b), 61 STAT. 155 (1947), 29 U.S.C. $\$ 178$ (b) (national emergencies); \$302(e), 61 STAT. 158 (1947), 29 U.S.C. \$186(e) (1952) (payments to employee representatives).

155. Senator Taft, in explaining his withdrawal of support from the Ball Amendment which permitted injunctions against violations of $\$ 303$, stated: ". . . I found that opposition to restoring the injunctive process even in cases of secondary boycotts and jurisdictional strikes, seemed to be so strong, and I am so anxious to retain . . . the right of direct action in suits brought for damages in cases of that kind,. that I shall vote against the Ball Amendment. . . " 93 Cong. REC. 5045 (1947).

156. W. I. Mead, Inc. v. International Brotherhood of Teamsters, AFL, 217 F.2d 6, 9 (1st Cir. 1954).

157. W. L. Mead, Inc. v. International Brotherhood of Teamsters, AFL, 217 F.2d 6 (1st Cir. 1954); Alcoa S.S. Co. v. McMahon, 81 F. Supp. 541 (S.D.N.Y. 1948), aff'd per curiam, 173 F.2d 567 (2d Cir. 1949); Sound Lumber Co. v. Lumber \& Sawmill Workers Únion, 122 F. Supp. 925 (N.D. Cal. 1954); Duris v. Phelps Dodge Copper Products Corp., 87 F. Supp. 229 (D.N.J. 1949); cf., in granting petition for remand, Pilot Freight Carriers, Inc. v. Bayne, 124 F. Supp. 605 (W.D.S.C. 1954) ; Associated Tel. Co. v. Communications Workers, CIO, 114 F. Supp. 334 (S.D. Cal. 1953) (alternate grounds); Castle \& Cooke Terminals, Ltd. v. Local 137, Int'l Longshoremen's Union, 110 F. Supp. 247 (D. Hawaii 1953); see Local 937, United Automobile Workers, CIO v. Royal Typewriter Co., 88 F. Supp. 669 (D. Conn. 1949) ; cf. California Ass'n of Employers v. Building \& Construction Trades Council, 178 F.2d 175 (9th Cir. 1949). 
governing terms or conditions of employment necessarily involves a controversy over them, and any suit alleging such a violation would therefore be within the broad definitions of Section 13 of the Norris-LaGuardia Act. ${ }^{158}$

In those cases which grant injunctive relief, the courts have developed three distinct approaches, all of which were conceived and applied in 301 suits. The first and least defensible is that of completely avoiding the Act by relying upon prior cases which neither discussed nor purported to involve the Act. The Sixth Circuit, in Milk \& Ice Cream Drivers, AFL v. Gillespie Milk Products Corp., ${ }^{159}$ reversed the dismissal of a union's suit for an injunction against the employer's breach, which consisted of a refusal to reinstate an employee in accordance with an arbitrator's award. The court summarily rejected the employer's contention that the Norris-LaGuardia Act forbade the injunction by citing its decision in American Federation of Labor v. Western Union Tel. Co. ${ }^{160}$ and stating "Although the Norris-LaGuardia Act was not under discussion, our opinion carried the necessary implication that the Act did not forbid the granting of the character of relief prayed." 101 The Western Union case in fact carried no such implication, ${ }^{162}$ for it merely reversed the dismissal of a suit not only for an injunction but also for a declaratory judgment that an employee was entitled to a pension, and the court confined its discussion of the available relief to the statement that "the Federal Declaratory Judgment Act vests in the federal court the right to grant the character of relief prayed." ${ }^{163}$ The Gillespie reliance upon the Western Union case is nothing more than a refusal to face the problem.

Another approach, adopted in the American Thread case ${ }^{104}$ in compelling submission of a dispute to arbitration, is that of holding that the Act was not intended to apply to the situation at hand. This approach has the advantage of resulting in a reasoned decision, since it requires inquiry into the intent and purposes of the Act and the application of current labor policies to the particular case..$^{165}$

Another theory used to permit injunctions in 301 suits is that of refusing to apply the Norris-LaGuardia Act to suits against employers. This theory first appeared in Mountain States Div. No. 17, Communication Workers v. Mountain States Tel. \& Tel. Co., ${ }^{166}$ in which the court enjoined an employer from terminating a collective bargaining agreement.

158. 47 Stat. 73 (1932), 29 U.S.C. \$113 (1952).

159. 203 F.2d 650 (6th Cir. 1953).

160. 179 F.2d 535 (6th Cir. 1950).

161. 203 F.2d 650, 651 (6th Cir. 1953).

162. See Associated Tel. Co. v. Communications Workers, 114 F. Supp. 334, 338 (S.D. Cal. 1953).

163. 179 F.2d 535, 538 (6th Cir. 1950).

164. 113 F. Supp. 137 (D. Mass. 1953).

165. See text at notes 108-09 supra.

166. 81 F. Supp. 397 (D. Colo. 1948). 
The court stated that "there is no labor dispute, no strike, fighting, violence or failure on the part of the local authorities to maintain order . . . [which are] the evils the Norris-LaGuardia Act was intended to protect the individual workman from." 167 This dubious reasoning was apparently advanced to support the court's otherwise untenable conclusion that the case did not involve a labor dispute.

The theory next appeared in a case compelling arbitration, ${ }^{168}$ and the Norris-LaGuardia Act was avoided by the proposition that this relief was not forbidden by Section 4 because that section was a limitation on behalf of employees. ${ }^{169}$ The court then granted the injunction, stating that the requirements of the Norrris-LaGuardia Act had been met. However, the required findings of fact were not even attempted, and the facts given show no possible basis for such a finding. ${ }^{170}$ Another court later denied summary judgment for defendant in a suit to compel arbitration because it doubted that the Act applied to suits against employers. ${ }^{171}$ The court apparently based its doubts on the above cases, although they were not cited. Other courts have regarded this theory as sufficiently strong to require the placing of a denial of an injunction against an employer on grounds apart from the Norris-LaGuardia restrictions. ${ }^{172}$ The theory does not deserve the recognition which it has been given since it finds no support in the Act itself; ${ }^{173}$ and even those courts which first adopted the reasoning were unwilling to rely fully upon it.

Some cases have granted injunctive relief at the suit of a union without discussion of the Norris-LaGuardia Act; ${ }^{174}$ others have denied relief

167. Id. at 400 .

168. Textile Workers, CIO v. Aleo Mfg. Co., 94 F. Supp. 626 (M.D.N.C.).

169. Id. at 629. Other sections of the Act were not discussed. The court distinguished the cases relied on by the employer on the grounds that they involved suits against a union.

170. See Note, 21 U. of CHI. L. Rev. 251, 263-64.

171. Local 877, United Automobile Workers, CIO v. United Aircraft Corp., 120 F. Supp. 186, 188 (D. Conn. 1952). This court in later cases has preferred to base its power to grant an order compelling arbitration upon an approach similar to that of American Thread rather than upon the inapplicability of the Norris-LaGuardia Act to employers. Compare Local 207, United Elec. Workers v. Landers, Frary \& Clark, 119 F. Supp. 877 (D. Conn. 1954), with International Union of Mine Workers v. American Brass Co., 126 F. Supp. 491, 493 (D. Conn. 1954).

172. In United Protective Workers v. Ford Motor Co., 194 F.2d 997 (7th Cir. 1952) the court affirmed the denial upon the ground that there was an adequate remedy at law, after rejecting the lower court's reasoning that the Norris-LaGuardia Act forbade the injunction, and after noting that the authorities were not in agreement. Id. at 1001. Compare International Longshoremen's Union v. Libby, McNeill \& Libby, 114 F. Supp. 249, 251, new trial denied, 115 F. Supp. 123 (D. Hawaii 1953) ( $\$ 301(a)$ includes suits for damages only), with International Union of Mine Workers v. American Brass Co., 126 F. Supp. 491, 504 (D. Conn. 1954) (pendency of action in state court).

173. See Note, 21 U. of CHI. L. Rev. 250, 261-62 (1954).

174. Local 397, United Automobile Workers, CIO v. Jacobs Mfg. Co., 120 F. Supp. 228 (D. Conn. 1953) ; Insurance Agents' Int'l Union, AFL v. Prudential Ins. Co., 122 F. Supp. 869 (E.D. Pa. 1954). 
on the merits, ${ }^{175}$ or because of the existence of an adequate remedy at law, ${ }^{176}$ or for mootness. ${ }^{177}$

Those cases which hold that injunctive relief is prohibited also may be classified. The first class consists of suits brought by the employer for an injunction against breach of a no-strike clause ${ }^{178}$ or against concerted refusal to work under the terms of the 'contract. ${ }^{179}$ Since this employee activity is specifically protected by Section 4 of the NorrisLaGuardia Act, ${ }^{180}$ injunctive relief in these instances is clearly forbidden. In the next group are those cases in which the injunctive relief was denied in suits by the union against the employer. In Duris v. Phelps Dodge Copper Products Corp., ${ }^{181}$ the national and local unions, having been expelled from the CIO, sued for an injunction against the employer and the newly formed CIO units to enjoin the defendants from applying to the new units the check-off, recognition, and grievance clauses of the existing contract. The court dismissed for lack of jurisdiction, holding that the suit, being a controversy over which of the two unions should function as the representative of the employees, was a "labor dispute" within the terms of the Act. ${ }^{182}$ In the case of United Packinghouse Workers $v$. Wilson $\&$ Co. ${ }^{183}$ the court dismissed the union's suit for an injunction against the employer's failure to abide by the contract during a strike which was permitted by a re-opening clause. After finding that a "labor dispute" was involved, the court reasoned that the Norris-IaGuardia Act removed jurisdiction to grant the injunction and that neither the amendments to Section 10 of the NLRA ${ }^{184}$ nor Section 301 (a) had restored it. Neither of these cases is directly opposed to those which state that the

175. Textile Workers, CIO v. Arista Mills Co., 193 F.2d 529 (4th Cir. 1951) (enforcement of seniority rights); Bakery \& Confectionery Workers v. National Biscuit Co., 177 F.2d 684 (3d Cir. 1949) (against pension plan); Industrial Trades Union v. Woonsocket Dyeing Co., 122 F. Supp. 872 (D.R.I. 1954) (submission to arbitration).

176. United Protective Workers v. Ford Motor Co., 194 F.2d 997 (7th Cir. 1952) (pension plan); Local 937, United Automobile Workers, CIO v. Royal Typewriter Co., 88 F. Supp. 669 (D. Conn. 1949) (breach of wage provisions).

177. Silverton v. Rich, 119 F. Supp. 434, 436 (S.D. Cal. 1954) (breach of union shop and wage provisions).

178. W. L. Mead, Inc. v. Teamsters Union, AFL, 217 F.2d 6 (1st Cir. 1954); Pilot Freight Carriers, Inc. v. Bayne, 124 F. Supp. 605 (W.D.S.C. 1954) (remanded); Sound Lumber Co. v. Sawmill Workers, 122 F. Supp. 925 (N.D. Cal. 1954); Morrison v. Local 682, Int'l Ass'n of Bridge Workers, AFL, 114 F. Supp. 54 (W.D. Ky. 1953) (injunction remanded and declaratory judgment retained); Castle \& Cooke Terminals, Itd. v. Local 137, Int'1 Longshoremen's Union, $110 \mathrm{~F}$. Supp. 247 (D. Hawaii 1953) (remanded; alternate holding).

179. Alcoa S.S. Co. v. McMahon, 173 F.2d 567 (2d Cir.), cert. denied, 338 U.S. 821 (1949).

180. 47 STAT. 70 (1932), 29 U.S.C. \$104 (1952).

181. 87 F. Supp. 229 (D.N.J. 1949).

182. "The term labor dispute includes any controversy . . concerning the association or representation of persons in negotiating, fixing, [and] maintaining ${ }^{\circ} \cdot$ terms or conditions of employment. . ."47 STAT. 70 (1932), 29 U.S.C. $\$ 113$ (c) (1952).

183. 80 F. Supp. 563 (N.D. III. 1948).

184. 61 Stat. 146 (1947), 29 U.S.C. \$ 160 (1952). 
Norris-LaGuardia Act runs in favor of employees only, since the injunction sought in the former would have been against the other union, and since the latter was also treated as alleging an unfair practice, over which the NLRB had exclusive jurisdiction. ${ }^{185}$

Although no consistent rationale can be drawn from the cases dealing with injunctive relief under Section 301(a), two patterns are apparent: (1) an order compelling an employer to submit to arbitration is available; (2) injunctive relief against concerted employee activity is prohibited. Certainly the second, and probably the first, of these patterns will be adhered to in future cases.

It remains doubtful whether an injunction may be had in other situations, but there is a greater probability where the union is the plaintiff. Despite the Sixth Circuit's issuance of an injunction at the behest of a union and the absence of any denial in any other circuit, the Sixth Circuit case should carry little weight, for it did not attempt to interpret the Norris-LaGuardia Act. The federal appellate courts will probably hold that Section 301 (a) did not override the injunction statute, ${ }^{186}$ but beyond that point there is no authority or indication of what will be the result.

\section{Proper Parties}

While it is clear that one essential element in the suits covered by Section 301(a) is the assertion of a violation of contract, nothing in the section or its legislative history limits such suits to those between the parties to the contract. ${ }^{187}$ However, the principle that the grant includes only suits between the parties to the contract sued upon has become firmly established without exception by the decisions. Where the issue is the propriety of parties plaintiff it is uniformly held that individual members of the union may not bring suit under Section 301(a), ${ }^{188}$ and that a member of an employer's association, being similarly situated, may not sue on a contract between the association and the union. ${ }^{189}$ There is no

185. 61 STAT. 146 (1947), 29 U.S.C. §160(a) (1952).

186. See text at note 157 and note 157 supra.

187. See Isbrandtsen Co. v. Local 1291, Int'l Longshoremen's Ass'n, 204 F.2d 495, 496 (3d Cir. 1953).

188. Evening Star Newspaper Co. v. Columbia Typographical Union, 124 F. Supp. 322 (D.D.C. 1954) ; Silverton v. Rich, 119 F. Supp. 434 (S.D. Cal. 1954); see United Protective Workers v. Ford Motor Co., 194 F.2d 997, 1000 (7th Cir. 1952); Durkin v. John Hancock Mutual Life Ins. Co., 82 F. Supp. 893, 11 F.R.D. 147, 148 (S.D.N.Y. 1950); Schatte v. International Alliance, 84 F. Supp. 669, 672 (S.D. Cal. 1949); Mackay v. Loew's Inc., 84 F. Supp. 676, 677 (S.D. Cal. 1949); Reed v. Fawick Airflex Co., 86 F. Supp. 822, 824 (N.D. Ohio 1949); cf. Snoots v. Wejlupek, 87 F. Supp. 503 (N.D. Ohio 1949).

Several cases contain statements which indicate that an individual was perhaps a party to the suit in addition to the plaintiff union. See Mercury Oil Refining Co. v. Oil Workers, 187 F.2d 980 (10th Cir. 1951); International Union of Operating Engineers v. William D. Baker Co., 100 F. Supp. 773, 774 (E.D. Pa. 1951) ; United Steel Workers v. Shakespeare Co., 84 F. Supp. 267, 269 (W.D. Mich. 1949); cf. United Packinghouse Workers v. Wilson Co., 80 F. Supp. 563 (N.D. I1l. 1948) (suit for injunction dismissed for want of jurisdiction).

189. Ketcher v. Sheet Metal Workers, 115 F. Supp. 802 (E.D. Ark. 1953). 
objection to the joinder of the individual's action, where independent grounds for jurisdiction over it are present. ${ }^{190}$ The Third Circuit, in holding for the defendant in a suit by the nonsignatory charterer of a ship against a union which breached a contract with a stevedoring firm, ${ }^{191}$ expressed some doubt as to the validity of the union's contention that only parties to the contract could be plaintiffs under 301(a), and declined to decide the case on that basis. However, the case which the court cited as raising the doubt, a suit by an employee discharged in violation of a collective bargaining agreement, ${ }^{192}$ was not brought under the section but under the general jurisdiction of the District of Columbia courts. ${ }^{193}$ There is no case holding that one not a party to a contract may sue for its breach under Section 301(a). This rule was rendered largely academic by the Supreme Court's decision in the Westinghouse case ${ }^{104}$ that Section 301(a) does not confer jurisdiction over suits under terms of the collective bargaining agreement which are peculiarly for the employees' benefit. This rationale eliminates from the coverage of the section those suits in which an individual is most likely to bring a suit, and in those cases which remain its net effect is the substitution of the union's name for that of the individual. The doctrine would still prevent a member of an employer association from bringing suit on the association's contract.

The requirement that the suit be between parties to the contract is also applied in determining the proper parties defendant. It has been held that individuals and an international union may not be sued for breach of a contract signed only by the local..$^{195}$ Section $301(b)$, which provides that "any money judgment against a labor organization . . . shall not be enforceable against any individual member or his assets," 186 does not control, for it governs only the effect of judgments against the organization and would not prevent judgments against the individual; ${ }^{197}$ nor would it have any effect where a union is not a defendant or where the suit is for relief other than a money judgment. One result of requiring defendants to be parties to the contract is the elimination from the coverage

190. United Protective Workers v. Ford Motor Co., 194 F.2d 997 (7th Cir. (1952). The employee's and union's causes must, of course, meet the requirements of the Federal Rules. See FED. R. Crv. P. 20.

191. Isbrandtsen Co. v. Local 1291, Int'1 Longshoremen's Ass'n, 204 F.2d 495 (3d Cir. 1953).

192. Marrahzano v. Riggs Nat. Bank, 184 F.2d 349 (D.C. Cir. 1950).

193. See Ketcher v. Sheet Metal Workers, 115 F. Supp. 802, 809-10 (E.D. Ark. 1953).

194. 75 Sup. Ct. 488 (1955). See text at notes 205-16 infra.

195. Square D Co. v. United Elec. Workers, 123 F. Supp. 776 (E.D. Mich. 1954); cf. Colonial Hardwood Flooring Co. v. International Union, United Furniture Workers, 76 F. Supp. 493 (D. Md. 1948) (on motion to dismiss complaint as to defendant International Union, issue of execution of contract by the International Union left for determination on the merits).

196. 61 STAT. 156 (1947), 29 U.S.C. 185(b) (1952).

197. Cf. Square D Co. v. United Elec. Workers, 123 F. Supp. 776 (E.D. Mich. 1954), in which the court did not refer to $\$ 301$ (b) in dismissing a suit against the individuals for money damages on the grounds that they were not parties to the contract. 
of Section 301(a) of actions based on a theory of conspiracy to breach or of inducing a party to breach the contract. Those few courts which have been faced with suits for interference with contractual relations have held them not to be within the jurisdiction conferred. In Square D Co. v. United Electrical Workers, ${ }^{198}$ the court dismissed a suit against a nonsignatory international union after rejecting the plaintiff's contention that the section included suits against those who conspired to breach the contract. Fay v. American Cystoscope Makers, Inc. ${ }^{199}$ denied a motion to remand to the state court a suit against an employer and a nonsignatory union which alleged in one count that the employer had breached the contract with plaintiff union and in another count that the employer and defendant union had conspired to breach the contract. The court stated that the allegations did "advance essentially a claim founded on breach of contract and ... . this . . . is not affected by the additional recitals of conspiracy." 200 This dictum indicates that the court would not have held a suit against a third party for the same conspiracy to be within Section 301(a), and at any rate the case is not authority for the inclusion of conspiracy actions since in removal cases the court may take jurisdiction of nonfederal causes which are part of an otherwise removable suit. ${ }^{201}$ In another case ${ }^{202}$ a court took jurisdiction of a suit against two unions, only one of which was a party to the contract, but apparently relied upon both Sections 301(a) and 303(b), ${ }^{203}$ and the Square D case distinguished it on this ground. ${ }^{204}$ Although these few cases alone cannot foreclose the inclusion of such suits within Section 301(a), there is no reason to treat the suits differently in this respect than those in which the requirement is applied to plaintiffs, and the latter cases can therefore be relied upon. In addition, the argument for excluding nonsignatory defendants is stronger than that for excluding plaintiffs. The latter cases differ in that a plaintiff can rely upon some rights conferred upon him by the contract while in the former the defendant is a stranger to the contract until he interferes with its performance. A suit against a nonsignatory defendant is more aptly described as a suit "for interference with contractual relations" than as one for "violation of a contract."

Prior to the Supreme Court's ruling in Association of Westinghouse Salaried Employees v. Westinghouse Electric Corp. ${ }^{205}$ the exclusion of

198. 123 F. Supp. 776 (E.D. Mich. 1954).

199. 98 F. Supp. 278 (S.D.N.Y. 1951).

200. Id. at 280 .

201. 28 U.S.C. $\$ 1441$.

202. R. O. Stenzel \& Co. v. Department Store Package Union, CIO, 11 F.R.D. 362 (W.D. Mo. 1951).

203. The court stated that $\$ 301$ "specifically provides for the institution and maintenance of suits for violation of contracts . - and [ $\$ 303]$ is more specific in relation to unlawful combinations. .... Id. at 363 . The court nowhere indicates that the picket lines of the non-contracting union were alleged to have been established for any of the purposes which would make them actionable under $\S 303$.

204. 123 F. Supp. 776, 781.

205. 75 Sup. Ct. 488 (1955). 
suits brought by the individual employee from the jurisdictional grant of Section 301(a) had not prevented its utilization to protect an employee against a breach of those provisions in the collective agreement which inured to his benefit, for the courts permitted the union to bring the suit on behalf of the injured employee. Without considering it necessary to discuss the possibility that they might be exceeding the limits of Section 301 (a), courts accepted jurisdiction over suits in which the union asserted the employee's right to wages, ${ }^{206}$ retirement benefits, ${ }^{207}$ vacation pay, ${ }^{208}$ and damages for breach of seniority rights. ${ }^{209}$ In the Westinghouse case the union brought suit under Section 301(a) alleging that the employer's refusal to pay 4000 employees their wages for a day on which they were absent from work was a violation of the terms of the collective bargaining agreement then in effect. The union sought a declaratory judgment interpreting the contract and judgments in favor of each employee. After a dismissal on the merits by the district court, 210 the Third Circuit dismissed for lack of jurisdiction on the ground that the duty to pay an employee arose from the individual contracts of hire and consequently the complaint alleged a violation of the contracts between each employee and the employer rather than a violation of the contract between the labor organization and the employer. ${ }^{211}$ The Supreme Court, Justices Douglas and Black dissenting, affirmed the dismissal for lack of jurisdiction, holding that the suit was not within the jurisdiction conferred by Section 301(a).

Each of the three opinions in support of dismissal is based upon the recognition of a distinction between rights which, though determined by provisions found within the collective agreement, are those of the individual employees, and rights which pertain to the union entity; but no more than three Justices could agree upon a rationale upon which the distinction is to be made. Justice Reed adopted a rationale similar to that of the majority of the Third Circuit.212 Chief Justice Warren, in a one paragraph opinion in which Justice Clark joined, excludes the suit because "the language

206. Silverton v. Rich, 119 F. Supp. 434 (S.D. Cal. 1954); Food Services Trades Council v. Retail Associates, Inc., 115 F. Supp. 221 (N.D. Ohio 1953); Lexington Federation of Tel. Workers v. Kentucky Tel. Corp., 11 F.R.D. 526 (E.D. Ky. 1951) ; Local 937, United Automobile Workers, CIO v. Royal Typewriter Co., 88 F. Supp. 669 (D. Conn. 1949); United Shoe Workers v. LeDanne Footwear, Inc., 83 F. Supp. 714 (D. Mass. 1949).

207. AFL v. Western Union Tel. Co., 179 F.2d 535 (6th Cir. 1950); cf. Textile Workers, CIO. v. American Thread Co., 113 F. Supp. 137 (D. Mass. 1953).

208. Local 793, United Automobile Workers, CIO v. Auto Specialities Mfg. Co., 15 F.R.D. 261 (W.D. Mich. 1951); United Automobile Workers v. Wilson Athletic Goods Mfg. Co., 119 F. Supp. 948 (N.D. I1l. 1950).

209. United Protective Workers v. Ford Motor Co., 194 F.2d 997 (7th Cir. 1952) ; Textile Workers, CIO v. Arista Mills Co., 193 F.2d 529 (4th Cir. 1951); Bakery \& Confectionery Workers v. National Biscuit Co., 177 F.2d 684 (3d Cir. 1949).

210. 107 F. Supp. 692 (W.D. Pa. 1952).

211. 210 F.2d 623 (1954) (Biggs, C.J., Hastie and Kalodner, JJ., dissenting), 102 U. of PA. L. Rev. 815, 63 YaLE L.J. 1173, 54 CoL. L. Rev. 1003 (1954),

212. See text at note 211 supra. Although the Third Circuit majority was not explicitly relied upon, the language and reasoning of the opinion is substantially similar. 
of $\S 301$ (a) is not sufficiently explicit nor its legislative history sufficiently clear to indicate that Congress intended to authorize a union to enforce in a federal court the uniquely personal right of an employee. . . ."213 Since Congress manifestly contemplated that the union could be a plaintiff in some Section 301 suits, the requirement of clearer and more explicit indications of Congressional intent assumes that the suit is not one for violation of a contract between the employer and the labor organization, which is the very question to be decided. The exclusion of this suit therefore depends upon its characterization as one asserting "uniquely personal" rights.

Justice Frankfurter's opinion, in which Justices Burton and Minton joined, also reads Section 301 (a) as not attempting to confer jurisdiction over this suit, but this interpretation results more from an attempt to avoid constitutional problems than from an analysis of the relationships created by collective bargaining agreements, or from an inquiry into congressional intent. Justice Frankfurter rejects the Third Circuit analysis because it denies the strong group interest in procuring for the employee the benefits of the collective agreement and encourages manifestation of this interest by way of strikes. ${ }^{214}$ The opinion indicates that, absent other factors, he would be inclined to permit the union to sue in this situation. After concluding that the section is purely procedural and discussing the constitutional difficulties which this conclusion raises, he states that these difficulties must be avoided "through the orthodox process of limiting the scope of doubtful legislation." Having decided that some limitation is necessary, Justice Frankfurter justifies the exclusion of this suit on the grounds that, because the section is procedural only, there is no need to burden the federal courts with litigation based upon a violation of those terms in the collective agreement which benefit the employee because the state courts recognize a cause of action in the individual employee.

This case does not present an appropriate occasion for resorting to an otherwise unnecessary limitation of the section in order to avoid constitutional problems, for the problems raised are equally present in all suits which the section permits. The limitation adopted here does not avoid the necessity of deciding the constitutional issues; it merely postpones decision until the court is faced with a suit which cannot be excluded on some other grounds. Consequently the distinction made by this opinion is between violations of those terms in the collective bargaining agreement which are of peculiar benefit to employees and which give a right of action to the individual employees, and those which do not.

Justices Douglas and Black, in dissent, considered the collective bargaining system as a whole and refused to recognize the importance of any distinction between the rights of the employees and those of the union. The suit was analogized to the grievance procedure and was viewed as but one aspect of the continuing, day-to-day administration of the collective

213. 75 Sup. Ct. 488, 501 (1955).

214. Id. at $498-99$. 
bargaining agreement, an aspect in which the union was thought to have a clear interest under the Act's concept of collective bargaining.

Although each of the opinions excluding the suit adopts a different rationale, the differences in approach probably will not lead to different results in the great majority of cases. All exclude suits relying upon provisions in the collective agreement which supply the terms and conditions under which the employee works and is to be paid, and all will presumably include suits for violation of those provisions under which the union acts as their representative. Between these two extremes lie those suits which contain elements of both, notably those involving arbitration clauses. Under the collective bargaining agreement the union participates in the arbitration procedure, and under the Act the union has a right to be present at the adjustment of grievances. ${ }^{215}$ If the employee's claim to an extra day's pay is subject to arbitration under the contract and the employer either refuses to submit to arbitration or refuses to be bound by the award, a question arises as to whether the union's suit to compel arbitration or to enforce the award would be within the Court's interpretation of the section. The obligation to arbitrate runs in favor of the union entity, but at the same time the right to wages which is being asserted is the same right involved in the Westinghouse case itself. Under Justice Reed's analysis of the genesis of the rights created by the agreement it would seem that both suits would be sustained as suits to enforce rights created by the arbitration clause, notwithstanding the fact that one result would be to enforce rights arising under the contract of hire. The opinions of Justices Warren and Frankfurter also would probably permit both. Neither suit is an attempt to enforce a "uniquely personal right" or is based upon clauses "peculiar in the individual benefit which is their subject matter." Moreover, refusal to arbitrate does not give rise to a cause of action in the individual employee. 216

Whatever the limitations which may be revealed by a close analysis of the theories and language found in the opinions, suits to compel arbitration and to enforce an award present a situation which is very different from that presented in the $W$ estinghouse case in so far as the relationships of employee, union and employer to one another are concerned. The decision is essentially a statutory interpretation and the opinions indicate that it would take little in the way of practical necessity to change the result in a given case.

\section{Conclusion}

Judicial construction of Section 301(a) during the eight years which have elapsed since its enactment has produced only doubts of its validity and uncertainty concerning its effect upon even the most basic problems

215. 61 STAT. 143 (1947), 29 U.S.C. $\$ 159$ (a) (1952). Section 8(d) includes in the duty to bargain a mutual obligation of the employer and representative to meet and confer with respect to ". . the negotiation of an agreement, or any question arising thereunder. ..." Id. at 142, 29 U.S.C. § 158(d).

216. United States v. Voges, 124 F. Supp. 543 (E.D.N.Y. 1954). 
of employer-union contractual relations. The courts have failed to develop a rationale which accords to arbitration its proper place in the day-to-day operations of collective bargaining agreements; the remedies available vary from court to court depending upon a particular court's interpretation of the Norris-LaGuardia Act and Section 301(a) itself; and some clauses of the collective contract are excepted from the operation of the section. This uncertainty stems from the inherent lack of clarity in Section 301(a) and clearly demonstrates that a grant of jurisdiction was an inept method of achieving the results desired by the legislature. Confronted with the grant of jurisdiction, the courts must choose between reading some substantive content into the section or holding it unconstitutional. If the Section is to be upheld, the courts are faced with an additional choice between developing federal concepts and rules or applying those of the states. The legislative history does not show that Congress intended that the federal courts should develop a federal common law, and such an excursion into the realm of labor policy should not be attempted without a clear mandate from the policy-making branch. The general confusion surrounding Section 301 (a) and the Westinghouse case itself are convincing evidence of the undesirability and futility of embarking upon such a task. On the other hand, a holding that the Section is unconstitutional would completely nullify congressional intent. Therefore, the substantive content of Section 301(a) should be limited to the principle of enforceability and questions of validity and interpretation should be resolved on this basis. 